\title{
Carbon Nanoparticles as Sources for a Cost-Effective Water Purification Method: A Comprehensive Review
}

\author{
Ankit Kotia $\left.{ }^{1}{ }^{(}\right)$, Aman Yadav ${ }^{1}\left(\mathbb{D}\right.$, Tata Rohit Raj ${ }^{1}$, Maria Gertrud Keischgens ${ }^{2}$, Happy Rathore ${ }^{3}$ \\ and Ioannis E. Sarris ${ }^{4, *}$ \\ 1 School of Mechanical Engineering, Lovely Professional University, Punjab 144411, India; \\ ankitkotia@gmail.com (A.K.); amanyaadav.097@gmail.com (A.Y.); rohitraj19120@gmail.com (T.R.R.) \\ 2 School of Fashion Design, Lovely Professional University, Punjab 144411, India; maria.24430@lpu.co.in \\ 3 Swami Vivekanand College of Pharmacy, Khandwa road, Indore 452020, India; \\ happy1927rathore@gmail.com \\ 4 Department of Mechanical Engineering, University of West Attica, 12210 Athens, Greece \\ * Correspondence: sarris@uniwa.gr
}

Received: 18 October 2020; Accepted: 17 November 2020; Published: 1 December 2020

check for updates

\begin{abstract}
As the global population grows, the demand for cost-effective and eco-friendly water purification methods is increasing, which presently is at its peak due to the increase of impurities in water and the increasing awareness of waterborne disease. Carbon-based materials, which includes activated carbon, carbon nanotubes (CNTs), graphene, graphene oxide (GO), reduced graphene oxide (rGO), fullerene, and carbon dots, are observed as potential candidates for water treatment. In the present review, developments related to water purification methods using carbon nanomaterials over the last decade are critically summarized, with an emphasis on their thermophysical properties. The fabrication techniques for activated carbon, CNTs, graphene, and graphene oxide are presented, with an emphasis on the properties of carbon materials that allow their usage for water purification. Then, an extensive review of 71 patents dedicated to water purification using carbon materials such as activated carbon and cotton fibers is performed. Subsequently, the more important research studies on water purification using carbon nanomaterials are discussed, showing that CNTs, GO, and rGO are widely used in water treatment processes. The present review critically discusses the recent developments and provides important information on water purification using carbon materials.
\end{abstract}

Keywords: water purification; carbon; thermophysical properties; structural properties

\section{Introduction}

Water is the most abundant and irreplaceable resource available globally, however despite its importance, water scarcity is occurring due to the rapid increase in the global population, intense industrialization, stringent water quality standards, and negative climate change [1]. Contamination with heavy metals (arsenic, iron, lead, mercury, chromium), microbes (Escherichia coli, Staphylococus), biological compounds, and other components (fluoride, cadmium) is widely encountered as major challenge related to water purification technology [1-3]. The rising challenge of pure water availability is reflected in UN models that project that 1.8 billion people will face water scarcity by 2025 . This is why the problem of water scarcity is listed in the Millennium Development Goals (MDGs) [2,4].

Conventional water treatment includes absorption, membrane filtering, and distillation processes [2-4]. Industrial effluent, agricultural waste water, sewage, and radioactive waste water are sources of contamination, as shown in Figure 1. Carbon nanoparticles can potentially be used for technological innovation in terms of improving water treatment due to being eco-friendly and cost-effective [5] and because of their specific surface area, strong sorption, fast kinetics [1], thermal 
stability, and conductivity [2,6,7]. Single-walled and multiwalled carbon nanotubes (CNTs, MWCNTs), graphene, and fullerene are among the most popular examples of carbon nanoparticles [1]. Graphene has been one of the most widely tested materials for water purification technology since its discovery in 2010 [4].

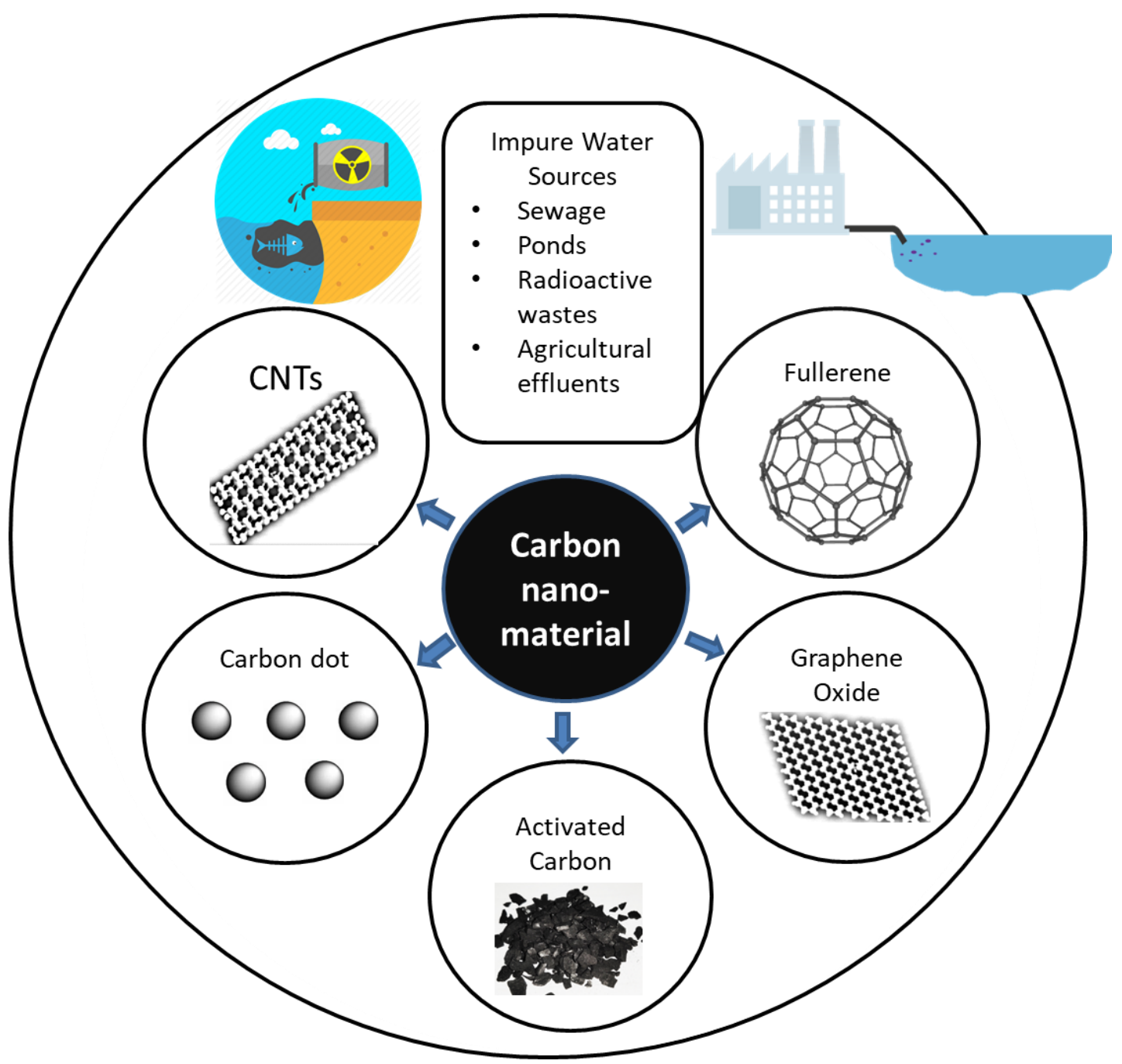

Figure 1. Use of carbon for water purification. CNTs, carbon nanotubes.

The structural properties of carbon nanomaterials such as CNTs, graphene oxide, carbon dots, fullerene, and activated carbon are largely responsible for their use in water purification technology. However, they also have some other additional characteristics that make them potential candidates. For example, the electrically conductive and selective ion transfer properties of CNTs could be important for desalination [8]. Additionally, 2D graphene is a versatile absorbent due to its high affinity to target contaminants because its surface functional groups, which are present on single sheets of carbon, are utilized to absorb heavy metals [6]. The formation of hierarchically structured layers allows absorption of heavy metals due to the formation of mesopores within the walls of the macropores [9]. Liu et al. [10] synthesized L-cysteine-functionalized MWCNTs for selective sorption of heavy metals and observed that the use of MWCNT-cysteine allows effective sorption of cadmium.

Activated carbon is a widely used material in existing water purification systems [11-16], due to its cost-effectiveness and availability. However, it has limited removal efficiency due to its low specific surface area, lower number of active sites, non-selectivity, and low absorption kinetics [17]. Activated carbon is a highly porous material with a heterogeneous range of pores (measuring approximately 
$<2 \mathrm{~nm}$ in diameter) that are present all around its internal structure [18]. These pores increase the specific surface area to up to $2500 \mathrm{~m}^{2} / \mathrm{g}$ [19]. Typically, activated carbon is made up of $80 \%$ carbon, with the remaining $20 \%$ composed of other elements such as oxygen and nitrogen [20,21].

CNTs are promising materials, as they are able to generate size-exclusion membranes, and due to their nanoscale features are capable of blocking the transport of certain microorganisms across these membranes. The main advantage of this is that the membranes can effectively filter bacteria from aqueous solutions, where the amount of CNT loading also has an effect on the virus filtration capacity [22]. An epoxy-entrapped, vertically aligned CNT material displayed similar antibiofouling properties, with physical damage and oxidative stress to microorganisms proposed as the mechanisms of action [23]. A more direct approach for fabricating antibacterial CNT water purification membranes was achieved with the incorporation of the natural bactericide nisin through adsorption onto CNTs [24]. The nisin-adsorbed CNTs were then coated onto a polycarbonate filter membrane, where bacteria become entrapped and are then neutralized. This approach provides a treatment method for nanometer-range bacteria.

Graphene oxide (GO) and reduced graphene oxide ( $\mathrm{rGO}$ ) are the two main derivatives of graphene [25]. Graphene oxide (GO) acts as a promising sorbent, having the ability to efficiently remove heavy metals and radionuclides. GO has attracted attention within the research community due to its extremely powerful separation ability. The presence of $-\mathrm{OH},-\mathrm{COOH},-\mathrm{C}=\mathrm{O}$, and other hydrophilic groups is the possible reason for this $[26,27]$. The highly functionalized operative surfaces of GO give it the potential to remove pollutants from water, as displayed in Figure 2 [28]. It can be observed that the graphene structure is only permeable to water molecules, and hence filters out impurities.

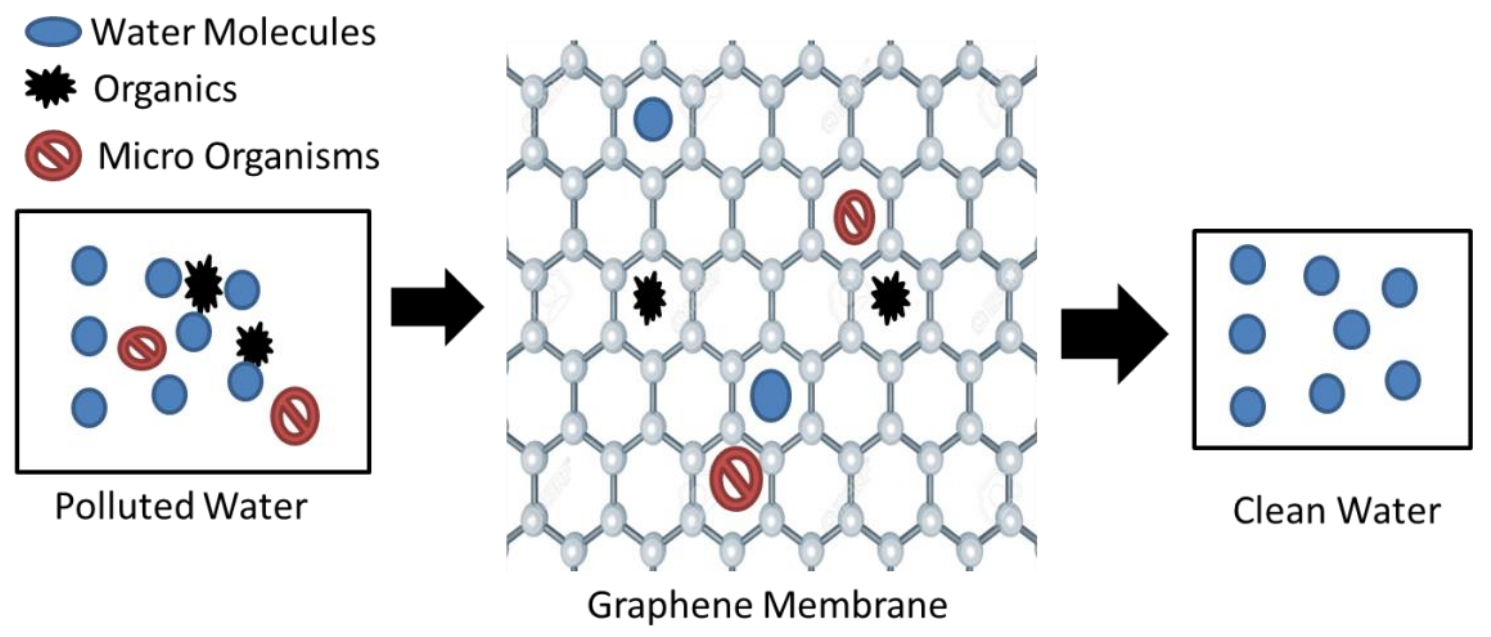

Figure 2. Graphene water purification method [28].

The vast technological advancements in water purification methods and significant contributions of carbon materials motivated us to prepare a detailed review of the topic. In order to keep the paper focused, the most appropriate articles were selected from Google Scholar, PatSeer, Scopus, and Science Direct databases. Combinations of keywords such as "water purification" and "carbon nanoparticles" were used. The focus was on studies published in the last decade. The date of the last search was 8 November 2020. Figure 3 shows the flow chart for relevant research article identification and selection. The selection of relevant articles was performed in two stages, as below.

- In the initial stage, the bibliographies were searched according to the article title and abstract. Moreover, relevant patents were identified based on the title and claim. Articles were filtered to meet the following three basic topic criteria: (a) water purification; (b) use of carbon nanoparticles; (c) subject related to cost-effective and eco-friendly technology. Additional papers were also 
searched from articles' reference lists. After review and exclusion of the database sources, 230 studies remained.

- In the second stage, the studies were read in full to identify the most relevant studies. Patents were also examined to identify the most appropriate ones. This process led to a final number of 151 potential studies.

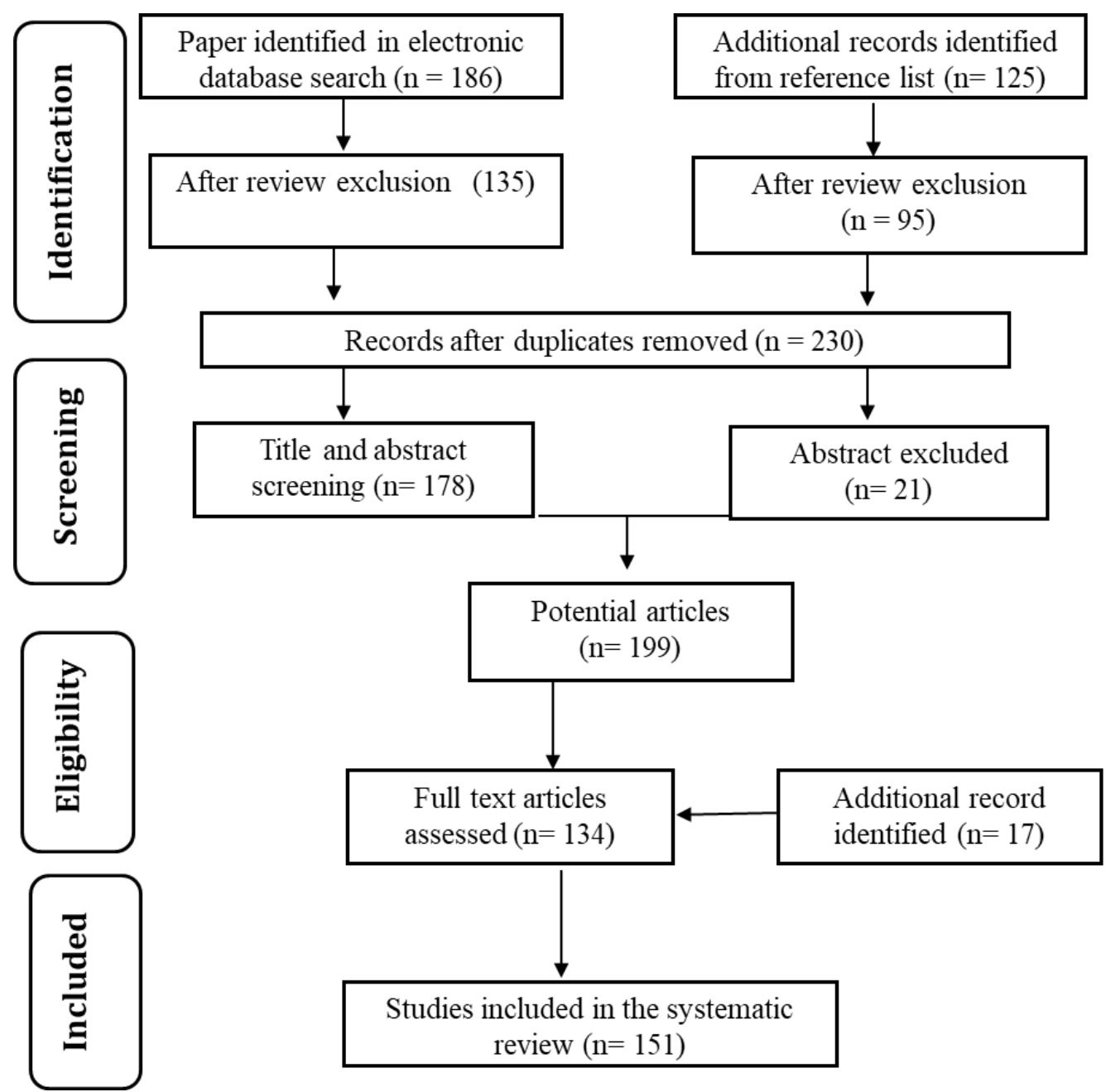

Figure 3. Flowchart of identification and selection strategy used for research articles.

Figure $4 \mathrm{a}, \mathrm{b}$ shows the chronological distribution of the recent publications and the geographical locations of the contributing authors for articles relating to water purification involving carbon-based nanoparticles. It can be observed that activated carbon, CNTs, and graphene are the most used carbon materials. This reflects the increase in attention from the research community towards testing carbon-based nanoparticles in water purification systems. Additionally, it can be observed that the researchers in this field are spread globally. 


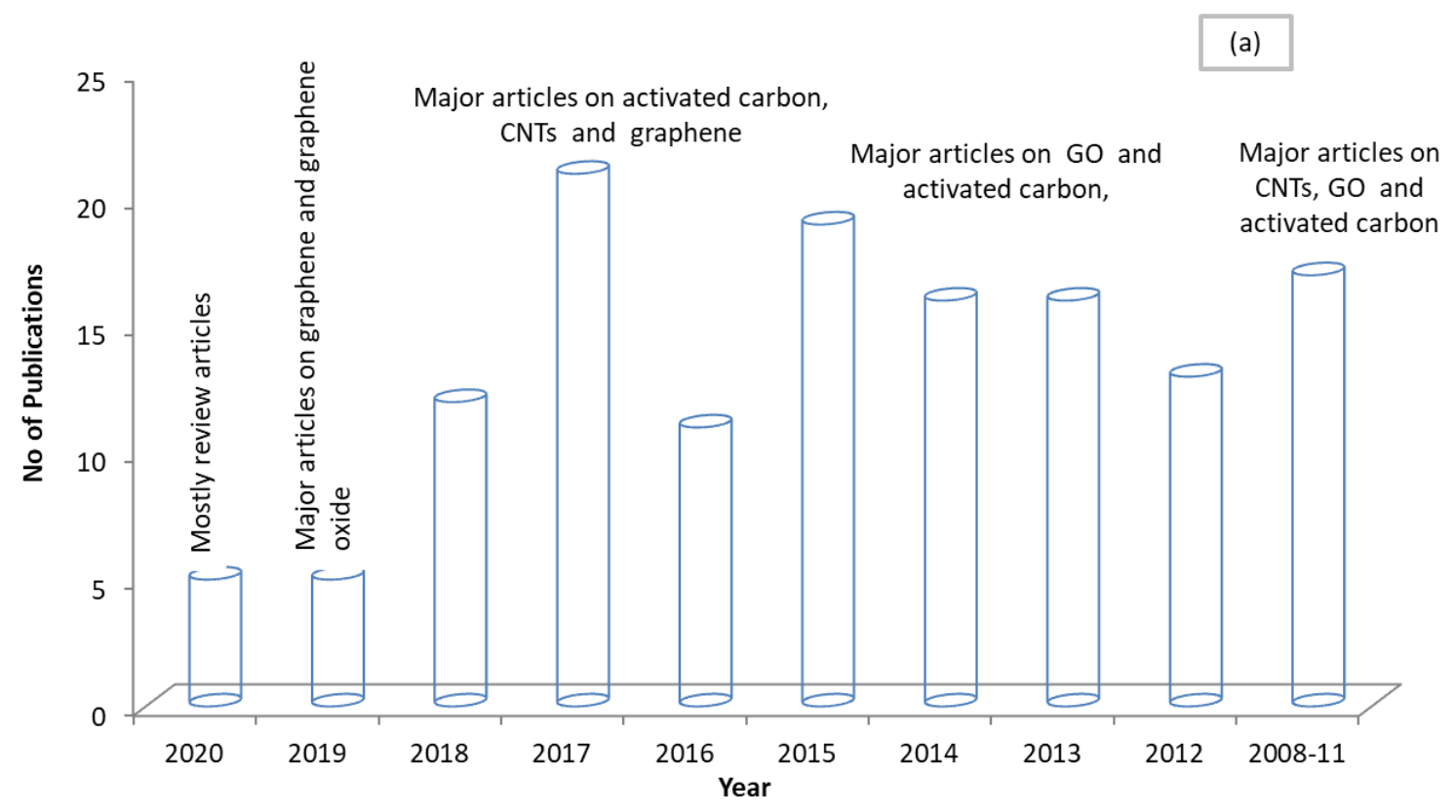

(a)

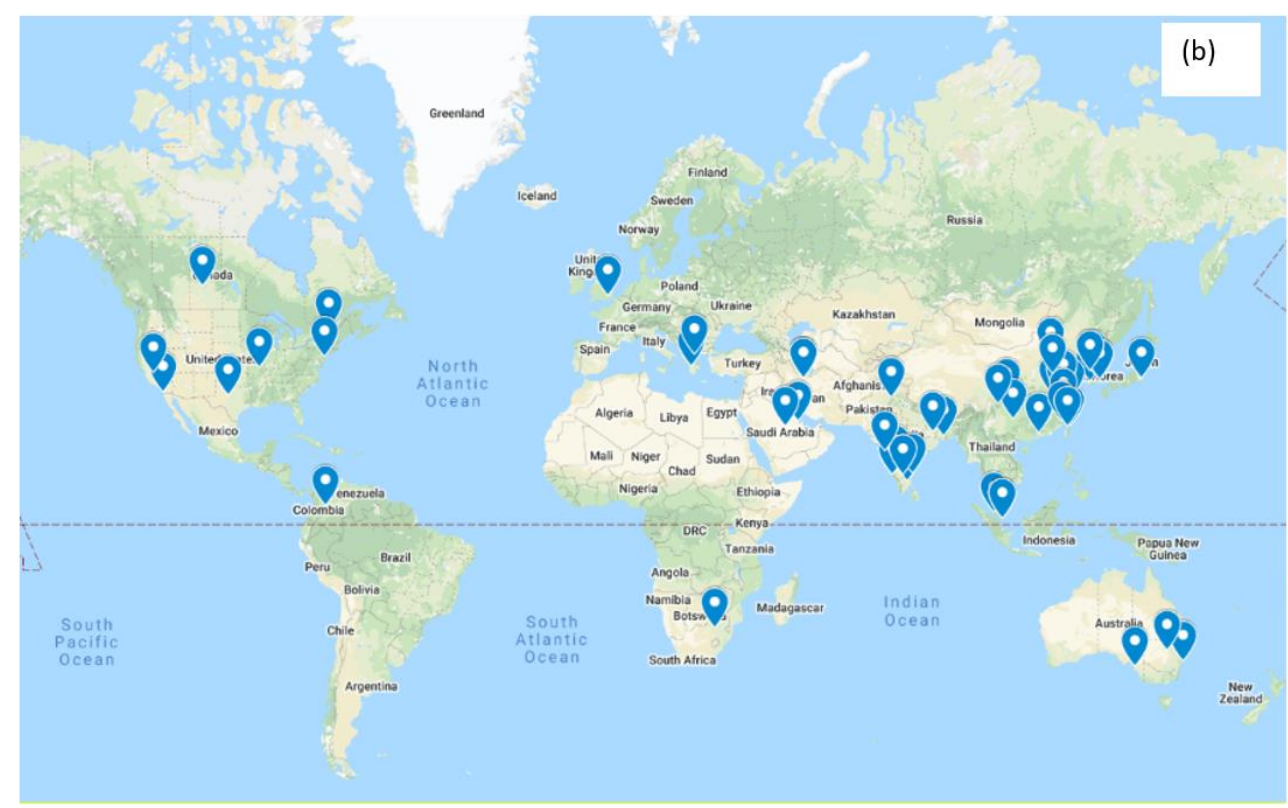

(b)

Figure 4. Representation of publications by year (a) and geographical location (b) from 2010-2020 for articles on water purification using carbon nanoparticles.

Carbon-based materials are gaining popularity due to their superior structural properties, ease of handling, eco-friendly nature, and cost-effectiveness. They are widely recommended for adsorption-based water purification methods due to their renewable nature [29]. The innovative use of carbon materials for water purification technologies is one of the focus areas within the research community, which can be observed from the 71 patents included in the present review. Carbon materials are used both alone and in composite structures, with fiber (basalt fiber) often used to improve the effectiveness [30,31]. Han et al. [32] prepared CNT-based photothermal nanocomposites and 
observed improved water purification via solar steam generation. Li et al. [33] prepared super-aligned carbon-nanotube-activated carbon composite electrodes and observed improvements in the water distillation capability. Among the articles, physical absorption, photodegradation, and solar-driven evaporation processes are widely studied [34]. The recent review on carbon-based nanoparticles for water purification provides insights on heavy metal removal [35], osmosis membranes [36], and carbon material properties [37]. The present review covers recent articles and patents related to water purification using carbon materials.

The present study reviews the recent developments in water purification technology using carbon materials. The initial section discusses carbon nanomaterial fabrication. The next section covers patents related to water purification using carbon materials from the last decade. It provides insights into recently developed water purification technologies. Further, recent research articles on water purification using activated carbon, CNTs, graphene, graphene oxide, and other carbon materials are discussed.

\section{Carbon Nanomaterial Fabrication}

Nanotechnology has emerged at the forefront of science and technology development. Carbon-based nanomaterials such as activated carbon, CNTs, graphene, carbon dots, and fullerene are major building blocks of this new technology. Due to their unique combination of electrical, thermal, and mechanical properties, the interest of the scientific community in potential applications of carbon nanomaterials in composites, electronics, computers, hydrogen storage, drug delivery, sensors, and many other related areas has grown rapidly $[19,31]$.

Activated carbon is formed from carbonaceous materials (bamboo, eucalyptus, lignite, coconut shell and husk), which makes it cost-effective, and hence widely used in water purification technology $[19,28]$. Figure 5 shows the granular activated carbon with its corresponding FESEM image. It can be observed that macropores are visible on its surface. In general, activated carbon is a crude form of graphite with a highly porous structure, containing pores of various sizes. It has a large number of cracks and crevices at the molecular level, which greatly increase its surface area. Activated carbon has an internal surface area of up to $1500 \mathrm{~m}^{2} / \mathrm{g}$. This enables activated carbon to carry out a phenomenon called adsorption, in which the molecules of a liquid or a gas are trapped by the internal or external surface of a solid. The structure of activated carbon is almost similar to that of pure graphite, since the $\mathrm{C}-\mathrm{C}$ bonds hold the hexagonal layers in the activated carbon molecules. The graphite crystals are composed of layers of fused hexagons held by weak van der Waals forces. The pore structure develops in the activated carbon, and thus the final properties of the activated carbon mainly depend on the raw materials and the production process [38].
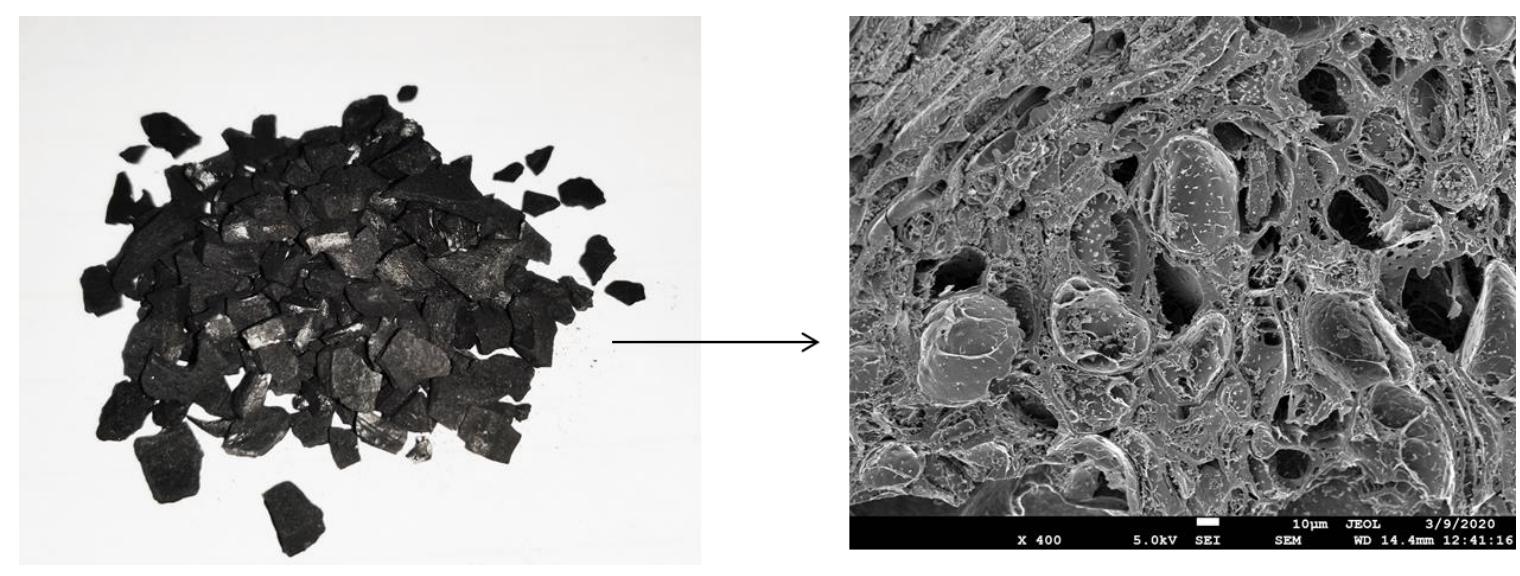

Figure 5. Macropores in activated carbon. 
Do et al. [28] formed an activated carbon- $\mathrm{Fe}_{3} \mathrm{O}_{4}$ nanoparticle composite for water treatment. This composite provided the combined features of activated carbon (absorption) and $\mathrm{Fe}_{3} \mathrm{O}_{4}$ nanoparticles (magnetic with catalytic properties). They used a coconut-shell-based powdered activated carbon. The presence of $\mathrm{Fe}_{3} \mathrm{O}_{4}$ nanoparticles in the pores of the activated carbon allows easy manipulation of the super paramagnetic properties. The authors observed the easy regeneration of the composite by washing with hydrogen peroxide due to the presence of $\mathrm{Fe}_{3} \mathrm{O}_{4}$, meaning it can be used repeatedly. The activated carbon- $\mathrm{Fe}_{3} \mathrm{O}_{4}$ nanoparticle composite is a potential absorbent catalyst that could be used for the removal of organic compounds, however its absorption capacity is gradually reduced with repeated regeneration.

A carbon nanotube can be considered as a graphene sheet that has been rolled up to make a seamless cylinder with a diameter as small as $0.4 \mathrm{~nm}$, with a length of up to a few centimeters, and half of a fullerene molecule in each end as a cap. CNTs come in various forms, such as single-walled carbon nanotubes (SWCNTs), double-walled carbon nanotubes (DWCNTs), and multiwalled carbon nanotubes (MWCNTs). SWCNTs consist of a single sheet of graphene forming a cylinder, as shown in Figure 6. The small diameter of CNTs means they are impermeable to impurities and makes them able to purify water. DWCNTs consist of two such cylinders in a concentric arrangement, whereas MWCNTs consist of an array of concentric cylinders that are positioned at a distance of $0.35 \mathrm{~nm}$ from each other. There are various ways to define the structure of carbon nanotubes. One possibility is to consider that CNTs may be obtained by rolling a graphene sheet in a specific direction, maintaining the circumference of the cross-section [39]. Since the microscopic structure of the CNTs is closely related to graphene, the tubes are usually labelled in terms of graphene lattice vectors. Two types of carbon nanotube (CNT) membranes can be fabricated, namely (i) vertically aligned (VA) and (ii) mixed matrix (MM) CNT membranes [40].

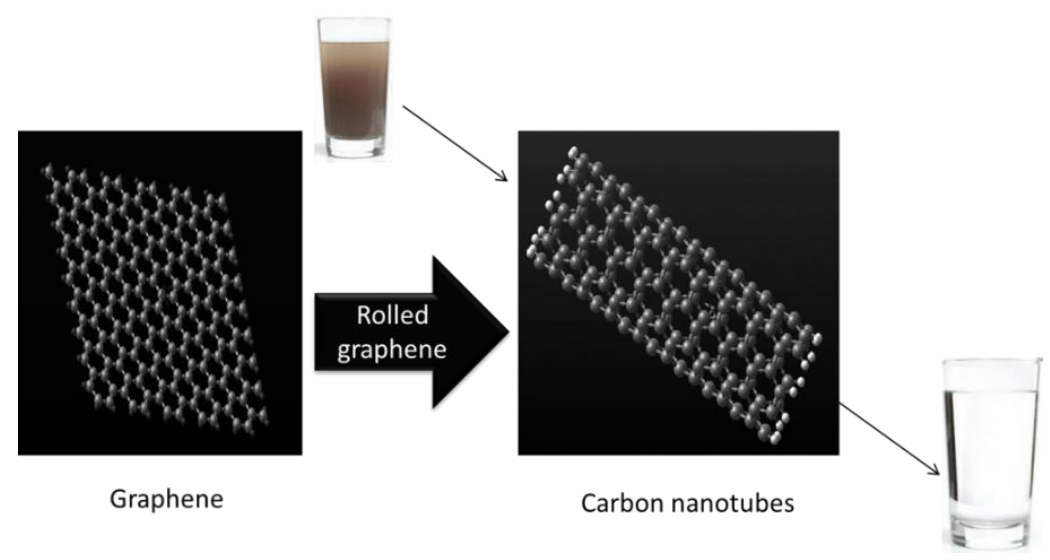

Figure 6. Use of CNTs for water purification.

Vertically aligned carbon nanotube (VA-CNT) membranes are synthesized by arranging perpendicular CNTs with supportive filler contents between the tubes, as shown in Figure 7 [25]. These membranes are molecular sieves with an intercalated filler matrix such as a polymer between them. The fillers may be epoxy, silicon nitride, or plastic resins with no water permeability. The fabrication procedure is simple but the pore sizes are irregular, means membranes are not able to retain $\mathrm{Ru}\left(\mathrm{NH}_{3}\right)_{6}{ }^{3+}$ ions initially following $\mathrm{H}_{2} \mathrm{O}$ plasma and $\mathrm{HCl}$ treatments. However, in a previous study, functionalization of a CNT core with negatively charged carboxylate groups trapped the positively charged $\mathrm{Ru}\left(\mathrm{NH}_{3}\right)_{6}{ }^{3+}$ ions [41]. The synthesis of homogeneous CNT membranes using laser vaporization, arc discharge, and pyrolysis is challenging due to the difficulty of controlling the diameter, length, and chirality. The chemical vapor deposition (CVD) approach is probably the best method for synthesizing VA-CNT membranes [42]. The use of catalysts in the CVD method ensures uniform CNT membranes of 20-50 $\mathrm{nm}$ in diameter and 5-10 $\mu \mathrm{m}$ in length [43]. 


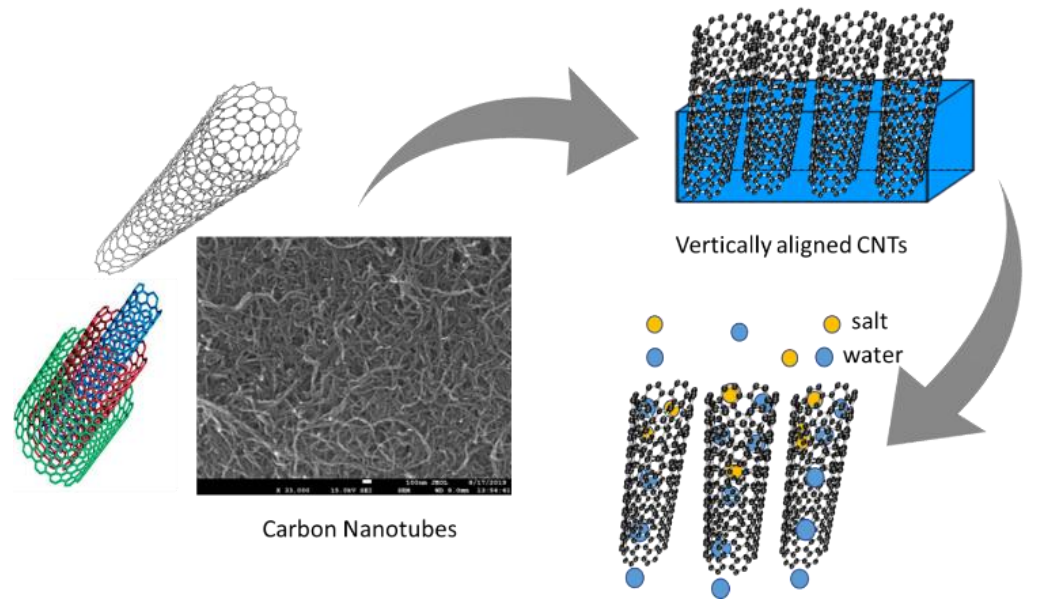

Figure 7. Schematic of CNT membrane fabrication [25].

Graphene oxide (GO) can be regarded as a typical two-dimensional oxygenated planar molecular material, with sp ${ }^{2}$ carbon atoms in a honeycomb structure [30]. GO is a non-stoichiometric chemical compound comprising carbon, oxygen, and hydrogen in a variable ratio, which largely depends on the processing methodologies [30]. It possesses abundant oxygen functional groups that are introduced into the flat carbon grid during chemical exfoliation, which present as oxygen epoxide groups (bridging oxygen atoms), carbonyl $(\mathrm{C}=\mathrm{O})$, hydroxyl $(-\mathrm{OH})$, phenol, and even organo sulfate groups. Figure 8 shows theoretical models of the structure of graphite or graphene oxide [31]. In 1936, Hofmann and Rudolf [44] proposed the first GO structure, in which numerous epoxy groups were randomly distributed on a graphite layer. In 1946, Ruess [45] updated the Hofmann model by incorporation hydroxyl entities and alternating the basal plane structure ( $\mathrm{sp}^{2}$ hybridized mode) with an $\mathrm{sp}^{3}$ hybridized carbon system (where $\mathrm{s} \& \mathrm{p}$ are atomic orbitals).

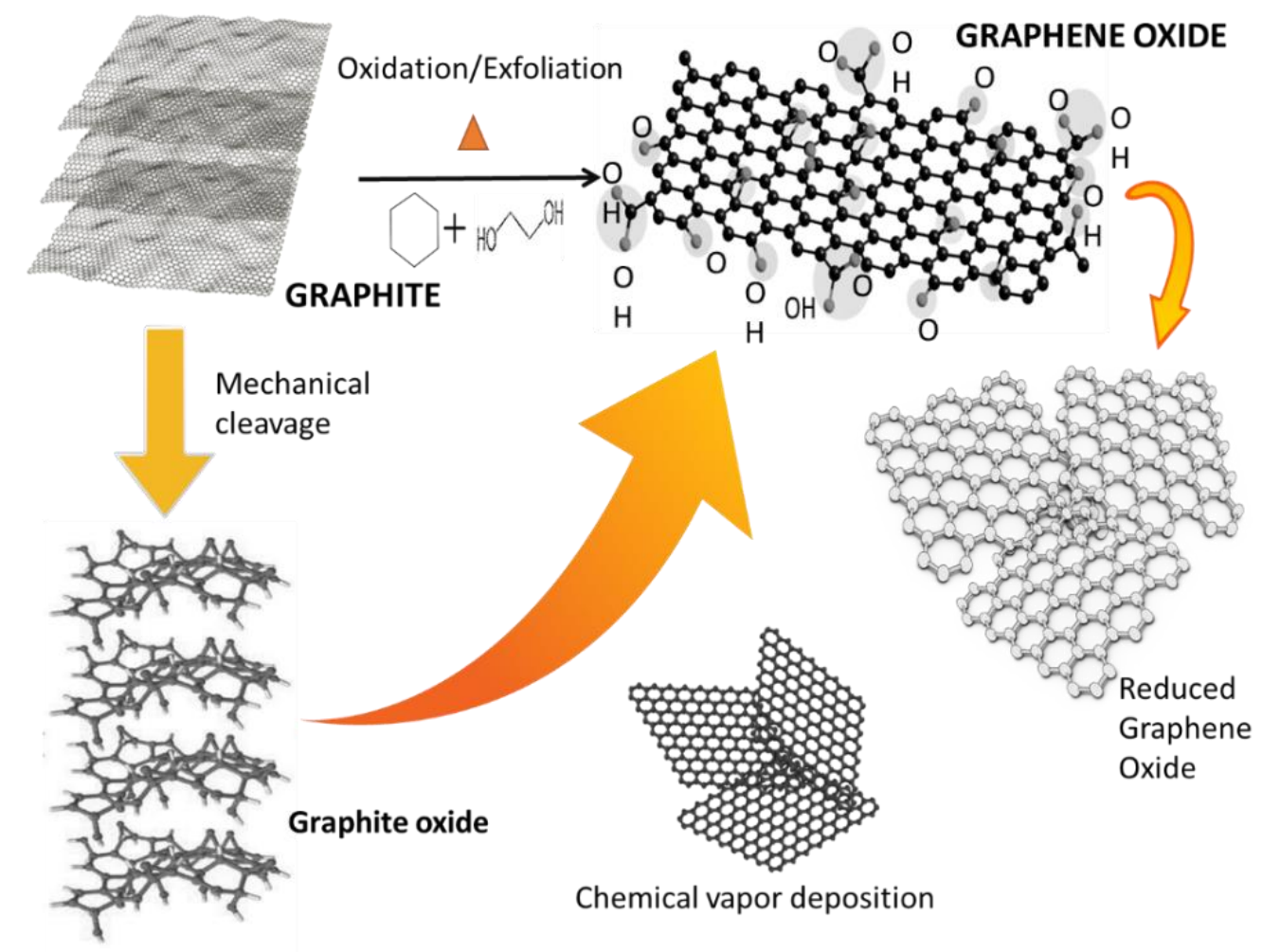

Figure 8. Theoretical models of the structure of graphite or graphene oxide [31]. 
In 2013, Dimiev et al. [30] revisited the structure via acid titration and ion exchange experiments in terms of the acidity of GO and proposed a novel dynamic structural model (DSM), which describes the evolution of several carbon structures with attached water molecules beyond the static Lerf-Klinowski (L-K) model. Amongst these models created from 1936 through to 2018, the L-K model has become the accepted basic model due to its interpretability for the majority of experimental data and ease with which it can be further adapted. However, knowledge about the structure of GO is still an ongoing argument.

Fabrication of graphene oxide (GO) membrane: A simplistic and efficient method for fabricating ultrathin reduced graphite oxide (rGO) membranes is shown in Figure 9. A modified Hummer's method is first used for the synthesis of the GO nanosheets measuring several micrometers in diameter [46]. A supported GO membrane is then formed on a mixed cellulose ester (MCE) filter by straining a diluted GO dispersion. This filtration method is not only simple and highly reproducible, but also allows precise and accurate control of the thickness of the GO layer [47]. Figure 9 shows the fabrication of rGO and its use for water purification. The color of the GO membranes formed on the MCE filter is light yellow. The resultant GO-MCE membrane is then placed above a hydriodic acid (HI) solution. Within 2-3 min, the GO membrane will quickly turned black, indicating that GO has reduced to rGO using $\mathrm{HI}$ vapor. Later, the rGO-MCE membrane is placed on the water's surface. Within 1 min, spontaneous separation of the rGO membrane from the MCE filter will be achieved. The MCE filter will sink to the bottom, while the ultrathin rGO membrane will float on the water's surface [48].
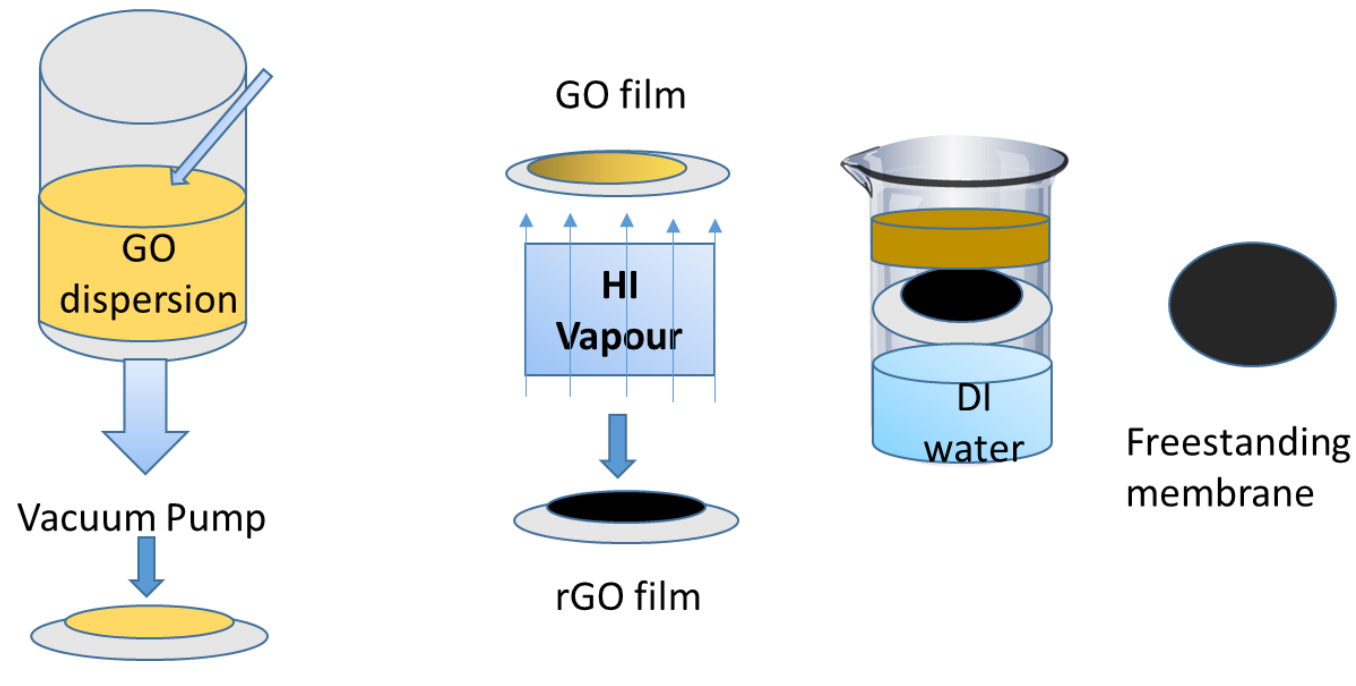

Freestanding rGO membrane

Figure 9. Fabrication of reduced graphite oxide (rGO) for water treatment [48].

\section{Recent Patents for Water Treatment Using Carbon Material}

This section explores the recent patents for water treatments using carbon materials. Activated carbon, GO, rGO, CNTs, fullerene, carbon dots, and carbon composites are widely used to develop and improve water purification technologies. This is reflected by the number of patents that integrate processes and technologies for use in small- and large-scale water purification. Table 1 lists patents related to water purification using carbon-based particles.

Patent CN109502896A [49] involves a water purifier that use graphene in membrane form along with polypropylene cotton, which can successfully remove impurities ranging from iron rust to dust. Patent CN107265530A [50] is a multiple-effect water purifier that utilizes acrylamide-oligomer-grafted oxidized graphene for purification, using processes such as flocculation and filtration to remove phenyl compounds and heavy metal ions. Patent CN108002366A [51] uses graphene in a completely different form, whereby a new kind of graphene water cleaning foam was made using solar energy, which can evaporate the moisture present in sewage using solar radiation, with a very high ion removal rate $(>99.5 \%)$ and high bacteria removal rate $(>99.9 \%)$, meeting drinking water standards. 
Patent US3612279A [52] involves a device containing four large perforated tubes wrapped with filter cloth coated with a mixture of activated powdered carbon, diatomaceous earth, and fibers. The four tubes are inserted into a tank fed at the bottom with impure water, which passes through the filter cloth, entering the tubes through perforations. Each of these tubes is connected on top, then finally a union pipe serves as an outlet for the filtered water. In this process, materials such as rust, sediment, chlorine, and other undesirable substances are left outside the tank. Patent US2014166591A1 [53] involves a water filter that utilizes granulated active carbon, along with two other technologies-ultraviolet " $\mathrm{C}$ " (UVC) and photocatalytic oxidation (PCO). In the beginning, the granulated active carbon particles are coated with titanium dioxide, which turns all of the surfaces into powerful semiconductors, triggering a powerful PCO process when UVC photons come into contact with them. The carbon particles absorb the organic compounds, while the other technologies finish the oxidation process. Additionally, this process can regenerate the carbon particles endlessly. Patent W02010144175A1 [54] involves a design in which activated carbon is used in the filtration mesh. The main objective of this design is to decrease the content of leachable arsenic present in water, which can be toxic if consumed. To achieve this, an adsorbent for leachable arsenic is introduced within the carbon particles at a concentration of less than 5\%. Tianye [55] developed an active carbon filter using active carbon from bamboo, along with other chemicals such as sodium hydroxide, potassium hydroxide, octadecyl acrylate, bentonite, and silicon dioxide. It contained a natural antibacterial agent that was added into the active carbon material. The filter process was economical, had a large absorption capacity, and did not create any secondary pollution.

Patent CN106830474A [56] involves a water purification system that can be used for healthy wine production using various filtration methods and processes. It contains an ultraviolet sterilizer, ultrafiltration membrane, precision filter, and an active carbon filter. All of these steps and processes are connected and the water is filtered through these systems. Patent CN109081477A [57] involves another filter that can be used for rural water supply and purification systems using a heavy metal ion treatment system, a water softening system, an activated carbon filter system, and adsorption layers that utilize graphene oxide, KDF55 alloy, and polyacrylic acid. It is claimed that the filter can purify toxic organisms and compounds and is easy to operate.

Patent CN10304386AJ [58] involves a three-stage filter that is used to tackle the problem of water loss and weak acid water production, which were the problems created by the filters currently available in the market. Therefore, the first stage involves microfiltration, as well as a composite molecular sieve; the second phase involves spherical preparation using active carbon and spontaneous medium-distance infrared rays; the last stage involves a nanofiltration membrane. Due to the requirement of low pressure, the absence of a pump saves energy. This design also manages to preserve water resources as intended. Patent CN209361991U [59] is a design for a household filter with an easy-to-replace activated carbon filter element. The design aims to eliminate the inconvenience faced by consumers by using a handy filter. Patent CN107298506A [60] involves an active carbon filter, wherein the purifier body is divided into a filtering cavity and an absorbing cavity, with the stirrers located in the filtering cavity. In the adsorbing cavity, numerous active carbon spheres are placed. The aim is that stirrers will speed up the water purification process. 
Table 1. Patents for water purification technologies involving carbon-based particles.

\begin{tabular}{|c|c|}
\hline Sr. No & Patent \\
\hline \multirow[t]{2}{*}{1} & CN109250781A [61] \\
\hline & $\begin{array}{l}\text { Invention related to water purifier using sintered activated carbon filter core, where rod-like activated carbon filter is prepared. } \\
\text { Grinding of activated carbon powder from coconut shells, ultra-high molecular polyethylene, negative ion powder, and tourmaline powder, followed by sintering heat treatment. } \\
\text { Advantages: Simple, feasible implementation, easily obtained raw materials, low cost, strong pollution removal ability, and long service life, and is suitable for large-scale } \\
\text { industrialized production. }\end{array}$ \\
\hline \multirow[t]{2}{*}{2} & CN203002379U [62] \\
\hline & $\begin{array}{l}\text { Model involves a silver-loaded activated carbon water purification filter element. } \\
\quad \text { It reduces the production cost on the basis of the filtering effect. }\end{array}$ \\
\hline \multirow[t]{2}{*}{3} & CN102126809B [63] \\
\hline & $\begin{array}{l}\text { Invention involves an ozone-biologically activated carbon water purification method and device. } \\
\text { Advantages as an activated carbon physical-chemical adsorption device, an ozone chemical oxidation device, and a biological oxidative degradation device are integrated. } \\
\text { Suitable for treating polluted and slightly polluted rivers, lakes, and water regeneration plants. }\end{array}$ \\
\hline \multirow[t]{2}{*}{4} & CN105481045A [64] \\
\hline & $\begin{array}{l}\text { The invention involves a negative-ion-sintered activated carbon water purification filter element. } \\
\quad \text { Cartridge prepared from active carbon powder ( } 65-75 \text { parts), negative ion composite powder (15-25 parts), polyethylene (5-15 parts), and water glass (0.5-5 parts). }\end{array}$ \\
\hline \multirow[t]{2}{*}{5} & CN209537118U [65] \\
\hline & $\begin{array}{l}\text { Model involves activated carbon water purification device for drinking water production. } \\
\text { Activated carbon filter element has a cylindrical structure and is mounted on the bottom wall of the base. }\end{array}$ \\
\hline \multirow[t]{2}{*}{6} & CN103055808A [66] \\
\hline & $\begin{array}{l}\text { Involves an activated carbon water purification device and preparation method. } \\
\text { Filling materials composed of an antimicrobial agent, acrylic acid polysaccharide, and high-efficiency activated carbon at weight ratios ranging from 2:3:1 to 2:5:2. } \\
\text { Overcomes limitations of the water color influence due to use of activated carbon. }\end{array}$ \\
\hline \multirow[t]{2}{*}{7} & WO2016190525A1 [67] \\
\hline & $\begin{array}{l}\text { Presents a large-capacity water treatment apparatus with an automatically activated carbon regeneration function. } \\
\quad \text { Waste water uniformly dispersed to pass though activated carbon, at the same time improving the regeneration performance. } \\
\text { Treating capacity is } 500 \text { tons or more per hour. }\end{array}$ \\
\hline
\end{tabular}


Table 1. Cont.

\begin{tabular}{|c|c|}
\hline Sr. No & Patent \\
\hline \multirow[t]{2}{*}{8} & CA1048940A [68] \\
\hline & $\begin{array}{l}\text { Involves activated carbon water purification for waste water containing dissolved organic carbon contamination. } \\
>\quad \text { Comprises constant withdrawal of deactivated carbon particles from the bottom and insertion of fresh or reactivated particles from the top. }\end{array}$ \\
\hline \multirow[t]{2}{*}{9} & CN103785223 [69] \\
\hline & $\begin{array}{l}\text { Invention involves preparation method for graphene oxide water purification filter core. } \\
\text { Comprises a filter tube, a filter core layer, and a protective layer. } \\
\text { It can effectively filter heavy metal ions and inhibit the breeding of microbes. }\end{array}$ \\
\hline \multirow[t]{2}{*}{10} & CN203803176U [70] \\
\hline & $\begin{array}{l}\text { It involves a self-cleaning active carbon filter cartridge device. } \\
\quad \text { Self-cleaning activated carbon filter devise is equipped with acid (hydrochloric acid) or alkali (sodium hydroxide) washing. }\end{array}$ \\
\hline \multirow[t]{2}{*}{11} & CN204058096U [71] \\
\hline & $\begin{array}{l}\text { It involves a water purifier with an activated carbon filter cartridge structure. } \\
\quad \text { It comprises granular activated carbon filter cartridge, } \mathrm{PPF} \text { filter cartridge, and RO membrane. } \\
\quad \text { The water purifier has the advantages of a simple structure, low cost, high removal rate, good water purification effect, and long service life. }\end{array}$ \\
\hline \multirow[t]{2}{*}{12} & CN204342473U [72] \\
\hline & $\begin{array}{l}>\text { It involves a household activated carbon filter cartridge. } \\
>\quad \text { It comprises activated carbon particles, a polypropylene framework, and activated carbon fiber felts. }\end{array}$ \\
\hline \multirow[t]{2}{*}{13} & CN101935114A [73] \\
\hline & $\begin{array}{l}\text { Invention involves a method for a negative-ion-sintered active carbon water purification filter core. } \\
\text { The negative-ion-sintered active carbon water purification filter core is very rigid and can be made by mixing the powdery active carbon, a natural functional material (one or } \\
\text { two parts negative ion powder and tourmaline powder), and a polymer bonding material. } \\
\text { Made of easily available raw materials, low cost, strong decontamination capability, long service life, and suitable for large-scale industrialized production. }\end{array}$ \\
\hline \multirow[t]{2}{*}{14} & CN103588257A [74] \\
\hline & $\begin{array}{l}\text { Involves a method for making a negative-ion-sintered active carbon water purification filter core. } \\
\text { The intensity of the water purification cartridge made from this sintering method is high, the adsorptive power is strong, and the formula is simple. Overall, this is a simple } \\
\text { process that efficiently removes the tangible pollution in the water. } \\
\text { Advantages are that the method is simple and easily-implemented, involves easily available raw materials, has low cost, strong decontamination capability, long service life, and } \\
\text { is suitable for large-scale industrialized production. }\end{array}$ \\
\hline
\end{tabular}


Table 1. Cont

\begin{tabular}{|c|c|}
\hline Sr. No & Patent \\
\hline \multirow[t]{2}{*}{15} & KR101495124B1 [75] \\
\hline & $\begin{array}{l}\text { The present invention relates to a carbon nanoparticle for a photocatalyst, which acts as a photocatalyst. } \\
\text { fullerene (C_6 or C_70) dispersed by an ultrasonic wave and having a hydrophilic functional group on the surface. } \\
\text { Fullerene nanoparticles shows excellent photocatalytic activity and provide potential option for water purification by maintaining the dispersion stability for a long time } \\
\text { regardless of changes in the underwater condition and being environment-friendly. }\end{array}$ \\
\hline \multirow[t]{2}{*}{16} & CN204918207U [12] \\
\hline & $\begin{array}{l}\text { Model involves an active carbon water purification filter core made from corn cobs. } \\
\text { It comprises a composite filter element with a PP fibrous layer, activated carbon layer, RO rate, and secondary activated carbon layer. } \\
\quad \text { It is cost-effective and eco-compatible. }\end{array}$ \\
\hline \multirow[t]{2}{*}{17} & CN201678532U [13] \\
\hline & $\begin{array}{l}\text { Invention involves an active carbon water purification device with automatic flushing and pollutant discharge functions. } \\
\text { In the water production, both the drainage and the electromagnetic exhaust valves are closed, the water valve is opened, and water passes through the activated carbon. The } \\
\text { drainage and electromagnetic exhaust valves are opened when water production has stopped. }\end{array}$ \\
\hline \multirow[t]{2}{*}{18} & CA2052200A1 [76] \\
\hline & $\begin{array}{l}\text { Water treatment apparatus consists of iodine resin purification bed supported in a walled structure and mounted upstream of an active carbon filtration bed. } \\
\text { Industrialization involves an ever-expanding problem of water pollution, either by way of chemical or microbial contaminants (i.e., bacterial, viral, or parasitic). } \\
\text { The small-volume treatment market approach has been to interject, upstream of the GAC, a purification element to devitalize (e.g., sterilize or kill) specific viruses and bacteria } \\
\text { prior to entering the bed. Such purification elements may also be mounted downstream of the bed to prevent reverse contamination. }\end{array}$ \\
\hline \multirow[t]{2}{*}{19} & EP2913300A1 [77] \\
\hline & $\begin{array}{l}\text { Invention relates to luminescent carbon dot nanoparticles for their preparation and use. } \\
\text { Carbon dots have advantage over heavy metal quantum dots, such as absence of toxic heavy metals, the high physicochemical stability, the very good dispersibility in water or } \\
\text { the continuous emission without blinking effects. } \\
\text { Carbon dots provides an potential option for water purification. }\end{array}$ \\
\hline \multirow[t]{2}{*}{20} & DE19946064A1 [15] \\
\hline & $\begin{array}{l}\text { The water heater consists of a water container holding a replaceable activate carbon water filter and at least one UV radiation source. } \\
\text { The benefit of the grain size of the activated carbon is to help in removal of dirt, lime, corrosion particles, and pesticides from water. }\end{array}$ \\
\hline \multirow[t]{2}{*}{21} & CN209397001U [16] \\
\hline & $\begin{array}{l}\text { Thin filter screen passes through screw. As it is mounted on the active carbon bottom portion, the micronic dust in the water can be filtered. } \\
\text { An activated carbon box is arranged on the sealing plate. } \\
\text { The fine filter screen is installed in the bottom of the activated carbon box with screws. The water purifier can easily filter water through the activated carbon. }\end{array}$ \\
\hline
\end{tabular}


Table 1. Cont.

\begin{tabular}{|c|c|}
\hline Sr. No & Patent \\
\hline \multirow[t]{2}{*}{22} & CN107352627A [78] \\
\hline & $\begin{array}{l}\text { Water purification composite materials comprise a substrate and } 2 \text { two-dimensional material layers, which are laminated on the substrate. } \\
\text { The first two-dimensional material layer and the second two-dimensional material layer are selected from black phosphorus, graphene, graphene oxide, graphdiyne, transition } \\
\text { metal chalcogenide, transition metal oxide, and transition metallic carbide. } \\
\text { This invention also provides a preparation method and an application for the water purification composite material. }\end{array}$ \\
\hline \multirow[t]{2}{*}{23} & JPS6295499A [79] \\
\hline & $\begin{array}{l}\text { Model involves a holder for an activated carbon filter cartridge. } \\
\text { The system consists of a magnetic recording device, whose recording speed is selectable. The speed of recording is } 1 / 3 \text { speed EP. }\end{array}$ \\
\hline \multirow[t]{2}{*}{24} & DE69103366T [80] \\
\hline & $\begin{array}{l}\text { This model involves an iodine resin-carbon water purification system } \\
\quad \text { Iodine resin purification bed supported in a walled structure and mounted upstream of an active carbon filtration bed. } \\
\quad \text { The purification bed includes a directionally permeable, replaceable, pointed housing, which mounts within the carbon bed. }\end{array}$ \\
\hline \multirow[t]{2}{*}{25} & US2014166591A1 [53] \\
\hline & $\begin{array}{l}\text { Purifier based on water disinfection (ultraviolet } \mathrm{C}, \mathrm{UVC} \text { ) and detoxification (photo catalytic oxidation, } \mathrm{PCO} \text { ). } \\
\text { The granular activated carbon is coated with titanium dioxide. } \\
\text { Carbon media absorbs organic compounds present in the incoming water, giving ample time for UVC and PCO to complete oxidation process. }\end{array}$ \\
\hline \multirow[t]{2}{*}{26} & US3612279A [52] \\
\hline & $\begin{array}{l}\text { The model consists of a carbon water filter } \\
\quad \text { Water passes through filter cloth, which is coated with a mixture of powdered activated carbon, diatomaceous earth, and fiber. }\end{array}$ \\
\hline \multirow[t]{2}{*}{27} & WO2010144175A1 [54] \\
\hline & $\begin{array}{l}\text { An activated carbon filter medium containing activated carbon and less than } 5 \% \text { arsenic adsorbent, which is filtered to remove the arsenic from the filter medium. } \\
\text { The arsenic adsorbent includes titanium, alumina, zirconium hydroxide, aluminum oxide, manganese oxide, diatomaceous earth, and ion exchange media. } \\
\text { A carbon filter containing less than about } 5 \% \text { titanium dioxide for reducing the leachable arsenic from the media of the filter. }\end{array}$ \\
\hline \multirow[t]{2}{*}{28} & TH53392B [81] \\
\hline & $\begin{array}{l}\text { The filter consists of an activated carbon mixture. } \\
\quad \text { The average activated carbon particles vary in size from } 65 \text { to } 75 \text { microns. }\end{array}$ \\
\hline \multirow[t]{2}{*}{29} & CN108190994A [82] \\
\hline & $\begin{array}{l}\text { A preparation method for a graphene water purifier filter core. } \\
\text { This method uses graphene oxide as a raw material, which helps to remove the harmful substances present in the water. } \\
\text { Advantages are simple structure, light in weight, effect of purification is good, and service life is long. }\end{array}$ \\
\hline
\end{tabular}


Table 1. Cont.

\begin{tabular}{|c|c|}
\hline Sr. No & Patent \\
\hline \multirow[t]{2}{*}{30} & CN108002366A [51] \\
\hline & $\begin{array}{l}\text { Graphene solar energy water cleaning foam, as well as a preparation method and application thereof. } \\
\text { The present invention relates to graphene solar energy water cleaning foam and its preparation method and purposes. } \\
\text { Outlines the water cleaning capacity deficiency of its unit mass material in particular surroundings (such as acidity, alkalescency, organic matter, heavy metal sewage, etc.) } \\
\text { The method used for cleaning and water preparation is very simple. By using solar radiation, the graphene solar energy water cleaning foam evaporates moisture in sewage so } \\
\text { that the water meets the drinking water standards. }\end{array}$ \\
\hline \multirow[t]{2}{*}{31} & CN107720976A [83] \\
\hline & $\begin{array}{l}\text { Water purification technology, more particularly a kind of compound used to purify water. } \\
\text { The compound has an excellent water-purifying function, is capable of absorbing a large quantity of hazardous substances and impurities. } \\
\text { The water-purifying effect is long lasting. } \\
\text { Removes toxic substances, greatly increases the ability to purify water, maintains the clean-up effect for a long period. }\end{array}$ \\
\hline \multirow[t]{2}{*}{32} & TW311477U [84] \\
\hline & $>$ An improved reverse osmosis-activated carbon water filter with automatic forced self-cleaning function. \\
\hline \multirow[t]{2}{*}{33} & CN107262042A [85] \\
\hline & $\begin{array}{l}\text { Development and manufacturing of basalt fiber, involving modified basalt fiber applied for water quality purification. } \\
\text { Unmodified basalt stone has problems of low efficiency, high cost, complicated operation, difficulties in treating low-concentration metals and bacterial pollutants. } \\
\text { The modified basalt fiber has a good removal effect on low-concentration metal ions, organic matter, and bacteria in water through physical-chemical adsorption. } \\
\text { The treated water quality meets the GB } 5749-85 \text { drinking water standards and the removal rate reaches } 99.9 \text { percent; therefore, the modified basalt fiber has good } \\
\text { application prospects. }\end{array}$ \\
\hline \multirow[t]{2}{*}{34} & CN106830474A [56] \\
\hline & $\begin{array}{l}\text { A pure water extraction system for healthy wine production. } \\
\text { Aqua purification extract system and method, improves the efficiency and water quality. } \\
\text { Magnetic valve is provided with raw water pump, level sensor is provided with raw water tank. The level sensor is connected with a solenoid signal. } \\
\text { The weep holes in the ultrafiltration membrane filter and each milipore filter are arranged along liquid transmission direction in a sinusoidal wave-shaped row. }\end{array}$ \\
\hline \multirow[t]{2}{*}{35} & CN103043836A [58] \\
\hline & $\begin{array}{l}\text { A drinking water terminal treatment purifier, particularly relates to energy-saving and water-saving advantages. } \\
\text { The energy-saving and water-saving water purifier design has the beneficial effects of operating at low pressure. } \\
\text { A first-stage filter provided with a microfiltration membrane and a composite molecular sieve. } \\
>\quad \text { A second-stage spherical preparation filled with active carbon, connected with a nanofiltration membrane. } \\
\text { A pressurization pump is not needed, meaning that electricity is not consumed and lots of energy is saved. } \\
>\quad \text { The water after the first-stage purification and the second-stage purification enters in the water purification tank to be utilized; lots of valuable water resources are saved. }\end{array}$ \\
\hline
\end{tabular}


Table 1. Cont.

\begin{tabular}{|c|c|}
\hline Sr. No & Patent \\
\hline \multirow[t]{3}{*}{36} & CN104058542A [86] \\
\hline & Involves multistage filter bed eddy flow magnetizing water purifier. \\
\hline & Outlines principles used to produce magnetization for healthy water that is useful to human body. \\
\hline \multirow[t]{4}{*}{37} & CN203269713U [87] \\
\hline & $>$ A rotational flow magnetizing water purifier with a dynamic and static combination multistage filter bed. \\
\hline & $>$ The rotational flow magnetizing water purifier comprises a stainless steel filtering jar and the dynamic and static combination multistage filter bed. \\
\hline & $>$ The multistage filter bed eddy flow magnetizing water purifier involves a structural representation of sound. \\
\hline \multirow[t]{3}{*}{38} & CN201962142U [88] \\
\hline & $>\quad$ The active carbon filter element and the reverse osmosis membrane are connected in turn. \\
\hline & Involves a compound molecule sieving filter element, active carbon filter core, and reverse osmosis membrane connected successively. \\
\hline \multirow[t]{5}{*}{39} & CN209361991U [59] \\
\hline & $>\quad$ An easy-to-replace activated carbon filter element of a household water purifier. \\
\hline & The domestic water purifier has the advantages that the domestic water purifier is simple in structure and convenient to disassemble. \\
\hline & $>$ The activated carbon filter element is easy to replace. \\
\hline & The problem of the existing domestic water purifier being inconvenient to replace because of the filter element is solved, meaning replacement is convenient. \\
\hline \multirow[t]{4}{*}{40} & CN204619525U [89] \\
\hline & $>\quad$ A novel highly efficient water purifier for modernized milling. \\
\hline & $\begin{array}{l}\text { Involves a water inlet, active carbon device, discharge regulating device, and water purifier regulation and control unit. The water purifier regulation and control unit is } \\
\text { provided to control discharge, regulating the device's top. }\end{array}$ \\
\hline & $\begin{array}{l}\text { The utility model involves the intake and the water purification surfaces, which are located on the water purifier's lower part, along with the raw water, and can reduce } \\
\text { the pollution. }\end{array}$ \\
\hline \multirow[t]{4}{*}{41} & CN107311378A [90] \\
\hline & $>\quad$ Involves a multifilter activated carbon water purifier. \\
\hline & Activated carbon is an excellent absorbent material, which is produce by with wood charcoal, bamboo charcoal, various shells, fat, coal, etc. \\
\hline & $>$ The present invention solves the technical problem by using a kind of activated carbon filter for multifiltering. \\
\hline \multirow[t]{4}{*}{42} & CN207016571U [91] \\
\hline & $>$ An energy-conserving and environmentally protective low-waste water purifier. \\
\hline & Pollution of the waterhead means that the running water used in everyday life is dangerous, and in this sense water security is lacking. \\
\hline & $\begin{array}{l}\text { The reverse osmosis membrane water purifier and the post active carbon is net non-return valve mounted between hydrophone and the combination filter element } \\
\text { water purifier. }\end{array}$ \\
\hline
\end{tabular}


Table 1. Cont.

\begin{tabular}{|c|c|}
\hline Sr. No & Patent \\
\hline \multirow[t]{2}{*}{43} & CN203938535U [92] \\
\hline & $\begin{array}{l}\text { A combined water purifier comprises the main body. } \\
\text { Polypropylene (PP) cotton filter element, the active carbon filter element and reverse osmosis (RO) membrane filter element are vertically arranged in the water purifier's main } \\
\text { body in parallel sequence } \\
\quad \text { The rear carbon filter element is horizontally arranged above the PP cotton filter element, the active carbon filter element, and the RO membrane filter element. }\end{array}$ \\
\hline \multirow[t]{2}{*}{44} & CN103145284B [93] \\
\hline & $\begin{array}{l}\text { Multifunctional water purifier integrated with activated carbon and low-temperature plasma. } \\
\text { It comprises a storage water tank, a vertical activated carbon bed, a water collecting tank, and a plasma reaction device. } \\
\text { The activated carbon and low-temperature plasma have the advantages of being highly integrated, low in cost, and easily processed, along with being stable and reliable in } \\
\text { terms of performance. }\end{array}$ \\
\hline \multirow[t]{2}{*}{45} & CN109502896A [49] \\
\hline & $\begin{array}{l}\text { Graphene water purifier is simple and compact in structure } \\
\text { Large silt, suspended solids, and iron rust are filtered by a precision stainless steel mesh. } \\
\text { - Fine silt, suspended solids, colloids, and dust in the water can be filtered by a PP cotton folding layer of polypropylene. } \\
\text { High-energy biochemical ceramic filter element separates micromolecular group water from macromolecular group water. } \\
>\quad \text { Silver-loaded activated carbon filter element is capable of effectively adsorbing organic matter from compounds, pesticides, and trichloromethane. }\end{array}$ \\
\hline \multirow[t]{2}{*}{46} & CN207108646U [94] \\
\hline & $\begin{array}{l}>\quad \text { Novel water purifier prevents frostbite. } \\
>\quad \text { This is an antipenetration water purifier that uses the freezing proof technique. }\end{array}$ \\
\hline \multirow[t]{2}{*}{47} & CN107298506A [60] \\
\hline & $\begin{array}{l}>\text { Active carbon water purifier with stirring and mixing functions. } \\
\text { Contains a filtering cavity and an adsorbing cavity on the upper layer and lower layer, respectively. } \\
>\text { Large and small granular quartz sand filtering layers are arranged in the filtering cavity in sequence from top to bottom. }\end{array}$ \\
\hline \multirow[t]{2}{*}{48} & CN109850977A [95] \\
\hline & $\begin{array}{l}>\text { Activated carbon purifier with backwashing function to replenish residual chlorine removal capability. } \\
>\quad \text { Forward and reverse washing removes the adsorbed substances between the surfaces and pores of the carbon particles. }\end{array}$ \\
\hline \multirow[t]{2}{*}{49} & CN208747829U [96] \\
\hline & $\begin{array}{l}>\quad \text { Model involves } \mathrm{RO} \text { water purifier. } \\
>\quad \text { Activated carbon core and RO membrane core provided with booster pump. } \\
>\quad \text { The multistage filtering knot structure makes replacement inconvenient. }\end{array}$ \\
\hline
\end{tabular}


Table 1. Cont.

\begin{tabular}{|c|c|}
\hline Sr. No & Patent \\
\hline \multirow[t]{4}{*}{50} & CN107473475A [97] \\
\hline & $>$ Energy-saving water purifier provided with multistage filtering functions. \\
\hline & Comprises a PP cotton filter core layer, an ultra-filter membrane core layer, a sintered active carbon filter core layer, an ultraviolet ray sterilizing lamp panel, and a display screen. \\
\hline & $>$ PP cotton filter core layer ensures removal of silt- and rust-type ultrafine impurities. \\
\hline \multirow[t]{3}{*}{51} & KR20030070267A [98] \\
\hline & $>$ Household water purifier for outdoor installation, with easy filter management \\
\hline & $>$ This consists of a precarbon filter, hollow fiber membrane filter, and postcarbon filter. \\
\hline \multirow[t]{3}{*}{52} & CN203728654U [99] \\
\hline & $>$ Ultrafiltration water purification machine. \\
\hline & $>\quad$ This comprises a primary water purifier using an ultrafiltration membrane and an activated carbon filter for secondary filtering. \\
\hline \multirow[t]{3}{*}{53} & CN204644006U [100] \\
\hline & $>$ Design for a family water purifier. \\
\hline & $>$ Active carbon filter core used to effectively remove chlorine residue and smell. \\
\hline \multirow[t]{3}{*}{54} & CN205346992U [101] \\
\hline & $>$ Comprises a rear-mounted, four-core water purifier. \\
\hline & $>$ Comprises an internal cotton filter core, leading active carbon filter core, compressed active carbon filter core, RO membrane, and postposition activated carbon filter element. \\
\hline \multirow[t]{3}{*}{55} & CN105800813A [102] \\
\hline & $>$ Invention related to a water-saving water purifier \\
\hline & $>$ It comprises PP cotton, granular-activated, carbon-integrated compressed carbon, RO membrane, and postactivated carbon. \\
\hline \multirow[t]{4}{*}{56} & CN204111513U [103] \\
\hline & $>$ The model provides a pressurized heating water purifier. \\
\hline & $>$ It consists of a high-density activated carbon rod filtering cylinder to adsorb heavy metals and impurities in water. \\
\hline & $>$ Magnetizer ensures scale prevention and removal rate greater than $98 \%$ \\
\hline \multirow[t]{3}{*}{57} & CN205473053U [104] \\
\hline & $>$ Comprises an outdoor water purifier. \\
\hline & $>$ It comprises an activated carbon filter core, oxidant filter core, vacuum fiber filter element, and pottery filter core. \\
\hline
\end{tabular}


Table 1. Cont.

\begin{tabular}{|c|c|}
\hline Sr. No & Patent \\
\hline \multirow[t]{5}{*}{58} & CN103979695A [105] \\
\hline & $>$ Comprises a high-precision ultrafiltration water purifier. \\
\hline & Liner consists of activated carbon arranged in the inner part of the water purifier's main body. \\
\hline & $>$ Activated carbon used to remove bad tastes, different colors, pollutants, and pesticides \\
\hline & $>\quad$ Alloy filter used to remove bacteria. \\
\hline \multirow[t]{2}{*}{59} & CN107867764A [106] \\
\hline & $\begin{array}{l}\text { It comprises an ultrafiltration unit outside the shell, RO filter inside the shell, carbon fiber filter, and activated carbon filter. } \\
\text { Muddy water from RO outlet sent for ultrafiltration. }\end{array}$ \\
\hline \multirow[t]{4}{*}{60} & CN204454785U [107] \\
\hline & $>$ Comprises an outdoor water purifier with a ceramic element. \\
\hline & $>$ Filter element is formed by connecting activated carbon filter element and a ceramic filter element. \\
\hline & $>\quad$ The additional use of silver-loaded activated carbon and ion exchange resin improves the water's taste, softens the water quality, and removes heavy metals. \\
\hline \multirow[t]{4}{*}{61} & CN206368080U [108] \\
\hline & $>$ Comprises an ultra-low pressure $\mathrm{RO}$ water purifier. \\
\hline & $>$ It comprises a first cotton filter core, activated carbon filtration core, and second cotton filter core. \\
\hline & $>$ Booster pump pressurization is not used for this ultra-low pressure $\mathrm{RO}$. \\
\hline \multirow[t]{3}{*}{62} & CN204224339U [109] \\
\hline & $>$ This is a wall-hung water purifier with an RO membrane filter element. \\
\hline & $>$ Combined filter elements: PP cotton filter element, an activated carbon filter element, an RO membrane filter element, and a rear activated carbon filter element. \\
\hline \multirow[t]{3}{*}{63} & CN207891156U [110] \\
\hline & $>\quad$ This is a model for recycling and purification of waste water. \\
\hline & $>$ It has a first filter screen for granule impurity, second filter screen, filter core body, and active carbon. \\
\hline \multirow[t]{4}{*}{64} & CN105384274A [111] \\
\hline & $>\quad$ This is a water purifier without waste water discharge. \\
\hline & $>$ It comprises a one-micrometer stainless steel filter, active carbon processor, $\mathrm{RO}$ membrane, and T33 filter. \\
\hline & $>$ RO membrane filter is provided with clean water and waste water outlets. The waste water outlet is connected to the first water pipe. \\
\hline \multirow[t]{3}{*}{65} & CN108217804A [112] \\
\hline & $>$ Involves an electrostatic activated carbon filter element for a water purifier. \\
\hline & $>$ Electrostatic sterilizing technology is used, along with the absorbing and filtering properties of activated carbon. \\
\hline
\end{tabular}


Table 1. Cont.

\begin{tabular}{|c|c|}
\hline Sr. No & Patent \\
\hline \multirow[t]{3}{*}{66} & CN208843834U [113] \\
\hline & $>$ This is a water-electricity separation water purifier. \\
\hline & $>$ It comprised PP cotton, granular activated carbon, and solid activated carbon filters. \\
\hline \multirow[t]{3}{*}{67} & CN202415284U [114] \\
\hline & This is a water purifier for tap water, which is convenient in terms of controlling the flow rate. \\
\hline & $>$ Its body comprises a ceramic filter cartridge layer, nanometal cluster filtering medium layer, and active carbon layer. \\
\hline \multirow[t]{4}{*}{68} & CN202808504U [115] \\
\hline & This is an RO water purifier with a pressure-free barrel. \\
\hline & $>$ It comprises an RO membrane filter with boost pump and back-activated carbon. \\
\hline & $>$ Compared with the prior model, this technical model has improved water yield due to adopting a large-flux RO membrane. \\
\hline \multirow[t]{3}{*}{69} & CN204550255U [116] \\
\hline & $>$ It comprises a panel with a display screen and its rear end is provided with a six-filter cylinder. \\
\hline & $>$ It has a PPF filter core, granulated active carbon filter core, extruded activated carbon core, RO membrane filter element, and bacteriostatic activated carbon filter core. \\
\hline \multirow[t]{3}{*}{70} & CN104671528A [117] \\
\hline & $>$ This is a constant-pressure water purifier with a purifying agent. \\
\hline & $>$ It comprises filters (PP cotton cartridges, activated carbon cartridges, and precision-activated carbon cartridges) and an RO treatment. \\
\hline \multirow[t]{3}{*}{71} & CN207192981U [118] \\
\hline & $>$ This is a vertical water purifier. \\
\hline & It comprises supreme quartz sand, a KDF layer, medical stone, magnetite, far-infrared living fossil, manganese sand, and the active carbon packaging. \\
\hline
\end{tabular}




\section{Recent Research Papers on Water Purification Using Carbon Material}

Access to pure drinking water is of the utmost importance for a healthy life. The search for eco-friendly and cost-effective methods for water purification has been a research priority for a long time. The increasing contamination (microorganism, chemicals, sediments, organic residuals) has made the research community accelerate its efforts. The use of carbon-based materials (activated carbon, CNTs, graphene, fullerene nanoparticles) for water purification has been widely investigated by research communities in the last decade, as observed from Table 2.

Nasrabadi and Foroutan [4] observed that CNTs have the potential to act as nanoelectrodes for separation of $\mathrm{Na}^{+}$and $\mathrm{Cl}^{-}$ions. They observed the nanoscale water purification (desalination) potential of CNTs using molecular dynamics simulations. The external electric field makes the $\mathrm{Na}^{+}$ move towards negatively charged CNTs and vice versa, leading to desalination. This study displays the potential applications of CNTs as efficient desalination nanomaterials. Ntim and Mitra [119] proposed a multiwalled carbon nanotube-zirconia ( $\left.\mathrm{MWCNT}-\mathrm{ZrO}_{2}\right)$ nanohybrid for use in the removal of arsenic traces in water. The MWCNT-ZrO ${ }_{2}$ nanohybrid absorbs AS(V) faster than AS(III). One of the major advantages is that the adsorption capacity is not a function of $\mathrm{pH}$. The adsorption rate of arsenic is two to three times slower than iron-coated MWCNTs, however the capacity is two to five times higher than iron-coated MWCNTs.

Beobide et al. [120] stated that industrial waste water contains highly biodegradable compounds. Due to these highly biodegradable compounds, it is not effective to use a membrane bioreactor (MBR) alone, so it is used in combination with nanofiltration or reverse osmosis. Surface-enhanced Raman spectroscopy (SERS) is used to measure the level of methyl blue (MB). MB is used in the textile industry as an aromatic dye. At a concentration of $500 \mathrm{ng} / \mathrm{mL}$ it affects the human nervous system. By using CNTs, there was a clear reduction in MB at $1622 \mathrm{~cm}^{-1}$. Bakajin et al. [121] used CNTs in their initial experimentation stage by considered the three important factors i.e. capital, energy and operational cost. CNTs have a uniform pore size, which eliminates the need for multistage pretreatment efforts. The membrane surfaces of CNTs are hydrophilic, making cleaning easy using backwashing or rinsing. Das et al. [122] stated that due to a lack of fresh water for daily usage purposes, CNTs were used for filtration, as they can remove the pollutants and salt from water. The usage of CNTs in water is becomes more effective than other conventional options due to the low energy consumption and antifouling and self-cleaning properties (CNT membranes have a self-cleaning capacity).

Masinga et al. [123] discussed the synthesis of nanocomposites of $\beta$ cyclodextrin polymers and nitrogen-doped carbon nanotubes under microwave irradiation. The polymers synthesized in the microwave showed better results in the removal of $\mathrm{PnP}$ from water than the conventional polymers. Zhang et al. [124] outlined a construction strategy for porous $\mathrm{TiO}_{2}$ nanotube carbon macroscopic monoliths (TNCMs). This material not only has a large surface area, porosity, and optical properties, but is also advantageous due to its adsorption properties and use of photocatalytic materials. TNCMs can be reused due to their robustness, facilitating organic waste water purification.

Nguyen-Phan et al. [125] prepared reduced graphene oxide-titanate (rGO-Ti) hybrids by including spherical $\mathrm{TiO}_{2}$ nanoparticles with graphene. The RGO sheets were used as a platform for the deposition of titanate, which showed much better results compared to pure materials. Sreeprasad et al. [5] showed a simple synthetic process for rGO-metal oxide composites and outlined their water purification applications. The primary cause for composite formation is the reaction between the rGO and metal precursor. The composites are used in water purification and can also be used in engineering and science fields, such as in catalysis and for fuel cells.

Peng et al. [126] worked on the removal of arsenate from water. The authors synthesized GO-FeOOH composites, showing excellent absorption of arsenate from water. This experimental procedure showed the three-dimensional matrix method is less efficient than using two-dimensional GO sheets. Sun et al. [127] fabricated graphene oxide-silver nanoparticles (GO-AgNPs) onto cellulose acetate (CA). In the filtration process, GO-AgNPs have higher standards of infiltration than the GO and silver membrane. The presence of GO-AgNPs provides strong antibacterial activity in the 
membrane. This study shows the good potential for antibiofouling membrane development for membrane separation.

Manafi et al. [128] observed that the insolvent phase polyacrylamide (PAM) -graphene-based nanocomposites were synthesized to allow better dispersion of graphene nanoplatelets in the matrix. This process was carried out using acid in the case of functionalized graphene nanoplatelets (FGNp) to achieve the fine dispersion found in the PAM matrix. In addition to GO, both the efficiency and supernatant turbidity decreased. There was a concentration change of GO and the water was cleaned efficiently. Moreover, Lompe et al. [129] showed that a composite material can be formed by combining powdered activated carbon (PAC) with the magnetic properties of iron oxide nanoparticles (NPs). The elimination of ammonia did not influence the iron oxide NPs on the PAC in a bioreactor. The PAC showed good performance in terms of both being adsorbent and removing biological growth in drinking water. Kim et al. [130] studied graphene-based nanofiltration membranes, which were used for water purification. By altering the level of arc discharge, the degree of oxidation increased from $28.1 \%$ at $1 \mathrm{~A}$ to $53.9 \%$ at $4 \mathrm{~A}$. Filters made of graphene sheets have excellent ion rejection capabilities compared to polyamide membranes. The high-carbon nanochannels show a tendency towards high water flux and show rejection in the case of hydrophobic interactions.

Yin et al. [131] demonstrated how graphene nanosheets are used in an in situ interfacial polymerization process. GO nanosheets have a multilayer structure. The spacing between layers was $0.83 \mathrm{~nm}$ and the GO nanosheets were dispersed in the polyamide, which improved the salt rejection in water. The $\mathrm{GO}$ nanosheets also rejected $\mathrm{NaCl}$ and $\mathrm{Na}_{2} \mathrm{SO}_{4}$ from water. GO sheets serve as water channels. The addition of different nanoparticle in carbon material also attempted to improve magnetic and other desired properties [132]. Pawar et al. [133] showed that the hydrothermal method can be used for the synthesis of MWCNTs and GO, where the nanostructure is based on single-crystal hematite $\left(\mathrm{Fe}_{2} \mathrm{O}_{3}\right)$. The samples were analyzed by performing different tests, such as $X$-ray diffraction, field emission scanning electron microscopy, and high-resolution electron microscopy tests. This technique involves lower fabrication costs for material formation and is also suitable for photocatalysis, having a high success rate for water purification. Sharma et al. [1] used graphene-carbon nanotube-iron oxide composites formed via the synthesis of carbon and iron-based nanomaterials for water purification. Due to the large surface area of graphene and graphene oxide, the absorption rate of impurities is higher. Magnetic-based nanomaterials are used to remove impurities and the extraction of nanomaterials from treated water is achieved by using external magnets. Tuan et al. [134] showed that capacitive deionization can be used for water purification to reduce the harshness of water by using an electrochemical double layer. There is extensive ongoing research on the use of reduced graphene oxide as a catalyst as compared to all other carbon-based materials. The efficiency of CDI was observed to be $3.54 \mathrm{mg}$ by using purified $\mathrm{rGO}$ as an electrode. 
Table 2. Studies on water purification.

\begin{tabular}{|c|c|}
\hline Sr. No & Author \& Remarks \\
\hline \multirow[t]{2}{*}{1} & Nasrabadi and Foroutan [4] \\
\hline & $\begin{array}{l}\text { Molecular dynamics (MD) simulation attempted to demonstrate the use of CNTs as nanoelectrodes for separation of } \mathrm{Na}^{+} \text {and } \mathrm{Cl}^{-} \text {ions form } \mathrm{NaCl} \text { solution. } \\
\text { The external electric field makes Na+ move towards negatively charged CNT and vice versa, leading to desalination. } \\
\text { Study displays the potential application of CNTs as efficient desalination nanomaterials. }\end{array}$ \\
\hline \multirow[t]{2}{*}{2} & Nguyen-Phan et al. [125] \\
\hline & $\begin{array}{l}\text { Reduced graphene oxide-titanate (RGO-Ti) hybrids were made by combining spherical } \mathrm{TiO}^{2} \text { nanoparticles with graphene. } \\
\quad \text { The RGO sheets were used as a platform for the deposition of titanate, which showed much better results compared to pure materials. }\end{array}$ \\
\hline \multirow[t]{2}{*}{3} & Sreeprasad et al. [7] \\
\hline & $\begin{array}{l}\text { This paper shows the simple synthetic process used for reduced graphene-metal oxide composites and their applications in water purification. } \\
\text { The primary cause of composite formation is the reaction between the RGO and metal precursor. } \\
\text { The composites were used for water purification and can also be used in engineering and science fields, such as for catalysis and fuel cells. }\end{array}$ \\
\hline \multirow[t]{2}{*}{4} & Ntim and Mitra [119] \\
\hline & $\begin{array}{l}\text { A multiwalled carbon nanotube-zirconia }\left(\mathrm{MWCNT}-\mathrm{ZrO}_{2}\right) \text { nanohybrid was used for removal of arsenic traces in water. } \\
\text { The MWCNT- } \mathrm{ZrO}_{2} \text { nanohybrid absorbs } \mathrm{AS}(\mathrm{V}) \text { much faster than } \mathrm{AS}(\mathrm{III}) \text {. One of major advantages is that the adsorption capacity is not a function of pH. } \\
\text { The MWCNT- } \mathrm{ZrO}_{2} \text { nanohybrid's adsorption rate for arsenic is two to three times slower than iron-coated MWCNTs, but the capacity is two to five times higher than } \\
\text { iron-coated MWCNTs. }\end{array}$ \\
\hline \multirow[t]{2}{*}{5} & Beobide et al. [120] \\
\hline & $\begin{array}{l}\text { Industrial waste water contains highly biodegradable compounds. Due to the presence of these highly biodegradable compounds, it is not effective to use a membrane } \\
\text { bioreactor (MBR) alone, so it was used with nanofiltration or reverse osmosis approaches. } \\
\text { Surface-enhanced Raman spectroscopy (SERS) was used to measure the level of methyl blue (MB). MB is used in the textile industry as an aromatic dye. } \\
\text { The concentration of } 500 \mathrm{ng} \backslash \mathrm{mL} \text { has effects on the human nervous system. By using CNTs there was a clear reduction in } \mathrm{MB}^{-1} 1622 \mathrm{~cm}^{-1} \text {. }\end{array}$ \\
\hline \multirow[t]{2}{*}{6} & Kar et al. [3] \\
\hline & $\begin{array}{l}\text { The application impact of carbon nanotubes (CNTs) in water technology is very high. } \\
\text { The ion rejection was not as high for desalination and monovalent salt rejection was not tested. The transport of ions and water through membranes ranging from } 6 \text { to } 11 \mathrm{~A} \\
\text { showed promising results for water desalination using a reverse osmosis process. } \\
\text { The use of CNT-based membranes for desalination and water purification is a tremendous achievement in water technology. }\end{array}$ \\
\hline
\end{tabular}


Table 2. Cont

\begin{tabular}{|c|c|}
\hline Sr. No & Author \& Remarks \\
\hline \multirow[t]{4}{*}{7} & Pudza et al. [135] \\
\hline & $>$ Carbon dots's absorption process was analyzed by Langmuir and Freundlich isotherms. \\
\hline & $>$ Carbon dots shows defined surface heterogeneity and exponential distribution of active size. \\
\hline & $>$ It makes potential material for waste water purification. \\
\hline \multirow[t]{4}{*}{8} & Xu et al. [136] \\
\hline & Graphene oxide $-\mathrm{TiO}_{2}$ was dispersed in water, which is stable. \\
\hline & $>$ The attached $\mathrm{TiO}_{2}$ and $\mathrm{GO}$ sheets have interlayer gaps that act as pores and make them potential filtration membranes. \\
\hline & $\begin{array}{l}\text { The properties of these films as filtration membranes for removal of dye molecules from water was shown. They captured additional amounts of dye molecules from water, } \\
\text { showing their significant application potential for water purification. }\end{array}$ \\
\hline \multirow[t]{3}{*}{9} & Peng et al. [126] \\
\hline & $>$ For the removal of arsenate from water, the author synthesized GO-FeOOH composites, which showed excellent absorption of arsenate from water. \\
\hline & $>\quad$ The experimental procedure showed that the three-dimensional matrix method is less efficient than using two-dimensional GO sheets. \\
\hline \multirow[t]{4}{*}{10} & Bakajin et al. [121] \\
\hline & Carbon nanotube (CNT) testing was performed in the initial stage. Three factors should be considered, which are the capital cost, energy cost, and operational cost. \\
\hline & $>$ CNTs have a uniform pore size, which eliminates the need for multistage pretreatment efforts. \\
\hline & > The CNTs' membrane surfaces are hydrophilic, making cleaning easy using backwashing or rinsing. \\
\hline \multirow[t]{4}{*}{11} & Das et al. [122] \\
\hline & $>$ Due to the lack of fresh water for daily usage purposes, CNTs are used for water filtration as they can remove pollutants and salt from water. \\
\hline & The usage of CNTs in water is become more useful than conventional methods due to their low energy consumption and antifouling and self-cleaning properties. \\
\hline & $>$ CNTs membranes have self-cleaning capacity. \\
\hline \multirow[t]{3}{*}{12} & Masinga et al. [123] \\
\hline & $>$ The authors discuss the synthesis of a nanocomposite involving a $\beta$ cyclodextrin polymer and nitrogen-doped carbon nanotubes under microwave irradiation. \\
\hline & $>$ The polymers synthesized in a microwave showed better results in terms of removal of $\mathrm{PnP}$ from water than the conventional polymers. \\
\hline
\end{tabular}


Table 2. Cont

\begin{tabular}{|c|c|}
\hline Sr. No & Author \& Remarks \\
\hline \multirow[t]{2}{*}{13} & Sun et al. [127] \\
\hline & $\begin{array}{l}\text { The author fabricated graphene oxide-silver nanoparticles(GO-AgNPs) onto cellulose acetate (CA). } \\
\text { In the filtration process, GO-AgNPs have higher standards for filtration than the GO and silver membrane. } \\
\text { The presence of GO-AgNPs provides strong antibacterial activity on the membrane. } \\
\text { This study showed the good potential for antibiofouling membrane development for membrane separation. }\end{array}$ \\
\hline \multirow[t]{2}{*}{14} & Zhang et al. [124] \\
\hline & $\begin{array}{l}\text { This paper outlined a construction strategy for porous } \mathrm{TiO}_{2} \text { nanotube carbon macroscopic monoliths (TNCMs) } \\
\text { This material has a large surface area, porosity, and optical properties, and is advantageous due to both its adsorption properties and the existence of photocatalytic materials. } \\
\text { TNCMs can be reused due to their robustness, facilitating organic waste water purification }\end{array}$ \\
\hline \multirow[t]{2}{*}{15} & Manafi et al. [128] \\
\hline & $\begin{array}{l}\text { In the solvent phase, plyacrylamide-graphite-based nanocomposites were synthesized. } \\
\text { For better dispersion of graphene nanoplatelets in the matrix, the process was carried out using acid in the case of FGNp to achieve the fine dispersion found in the } \\
\text { PAM matrix. } \\
\text { With the addition of GO, both the efficiency and supernatant turbidity decreased. As the GO concentration changes, water cleaning efficiency also changed. }\end{array}$ \\
\hline \multirow[t]{2}{*}{16} & Lompe et al. [129] \\
\hline & $\begin{array}{l}\text { A composite material was formed by combining powdered activated carbon (PAC) with the magnetic properties of iron oxide nanoparticles (NPs). } \\
\text { The elimination of ammonia and dissolve organic carbon did not influence the iron oxide nanoparticles on the PAC in a bioreactor. } \\
\text { The PAC showed good performance in terms of both being adsorbet and removing biological growth in drinking water. }\end{array}$ \\
\hline \multirow[t]{2}{*}{17} & Kim et al. [12] \\
\hline & $\begin{array}{l}\text { Graphene-based nanofiltration membranes were used for the water purification process. } \\
\text { By altering the level of arc discharge, the degree of oxidation increased from } 28.1 \% \text { at } 1 \mathrm{~A} \text { to } 53.9 \% \text { at } 4 \mathrm{~A} \text {. } \\
>\quad \text { Filters made of graphene sheets had excellent ion rejection capability compared to polyamide membranes. } \\
>\text { The high-carbon nanochannels showed a tendency towards high water flux and rejected the hydrophobic interaction. }\end{array}$ \\
\hline \multirow[t]{2}{*}{18} & Yin et al. [131] \\
\hline & $\begin{array}{l}\text { Graphene nanosheets were formed via the in situ interfacial polymerization process. GO nanosheets have a multilayer structure. The spacing between the layers is } 0.83 \text { nm. } \\
\text { GO nanosheets were dispersed in the polyamide and their membranes improved, indicating good salt rejection in water. } \\
\text { GO nanosheets also rejected } \mathrm{NaCl} \text { and } \mathrm{Na}_{2} \mathrm{SO}_{4} \text { from water and the GO sheets served as water channels. }\end{array}$ \\
\hline
\end{tabular}


Table 2. Cont

\begin{tabular}{|c|c|}
\hline Sr. No & Author \& Remarks \\
\hline \multirow[t]{2}{*}{19} & Tuan et al. [134] \\
\hline & $\begin{array}{l}\text { Capacitive deionization was used for water purification and to reduce the harshness of water by using an electrochemical double layer. } \\
\text { Extensive ongoing research works are investigating reduced graphene oxide as a catalyst compared to all other carbon-based materials. } \\
\text { The efficiency of CDI was observed to be } 3.54 \mathrm{mg} \text { when using purified rGO as an electrode. }\end{array}$ \\
\hline \multirow[t]{2}{*}{20} & Gondal et al. [132] \\
\hline & $\begin{array}{l}\text { Pulsed laser ablation in liquid technique is used for synthesis of } \mathrm{SiC}_{-} \mathrm{TiO}_{2} \text { semiconducting nanocomposite. } \\
\quad 0.6-1.65 \% \text { improvement is observed in photo-conversion efficiency and } 22-77 \% \text { enhancement in methyl orange dye removal. with } 10 \% \text { weight of silicon carbide. } \\
\text { The improvement in conduction of electrons due to presence of silicon carbide in titanium oxide is responsible for this enhancement in dye removal and hence water } \\
\text { purification capacity. }\end{array}$ \\
\hline \multirow[t]{2}{*}{21} & Pawar et al. [133] \\
\hline & $\begin{array}{l}\text { Single crystal } \mathrm{Fe}_{2} \mathrm{O}_{3}, \mathrm{rGO} \text { and functionalized } \mathrm{MWCNTs} \text { based nanostructured composite synthesized via hydrothermal method. } \\
\text { Uniform dispersion of MWCNTs and } \mathrm{rGO} \text { with } \mathrm{Fe}_{2} \mathrm{O}_{3} \text { results in increased specific surface area, optical absorbance and favorable charge transport property. } \\
\text { This cost effective fabrication technique of composite material has potential application in water purification. }\end{array}$ \\
\hline \multirow[t]{2}{*}{22} & Hegab and Zou [137] \\
\hline & $\begin{array}{l}\text { Graphene oxide was used to improve the membrane properties in the desalination process. In this way the membranes increased their mechanical strength and water flux } \\
\text { and also improved their thermal properties. } \\
\text { GO was used as a catalyst and helped in the removal of dyes from the water from textile and industrial waste. } \\
\text { The lower manufacturing and operational costs for GO membranes make this approach more effective. GO membranes provided promising results for water purification } \\
\text { and could help to ease the water crisis. }\end{array}$ \\
\hline \multirow[t]{2}{*}{23} & Gamage and Sathasivan [138] \\
\hline & $\begin{array}{l}\text { The author used biologically activated carbon }(\mathrm{BAC}) \text { as a purification agent to remove organic matter present in drinking water. } \\
\text { BAC plays a very important role in removing hydrophilic fractions and many toxic impurities during the water purification process. } \\
\text { If the process is adopted and executed properly, BAC can solve many of the problems related to water availability. }\end{array}$ \\
\hline \multirow[t]{2}{*}{24} & Raghu et al. [139] \\
\hline & $\begin{array}{l}\text { In this study the authors synthesized a graphene composite with } \mathrm{Fe}_{3} \mathrm{O}_{4} \text {. } \\
\text { It was used as an alternative to absorb dye present in aqueous solutions. } \\
\text { The GO-Fe } \mathrm{Fe}_{3} \mathrm{O}_{4} \text { was tested for both Gram-positive and -negative bacterial strains such Bacillus subtilis and antimicrobial activities, showing that it can be used for dual } \\
\text { purposes in water treatment. }\end{array}$ \\
\hline
\end{tabular}


Table 2. Cont

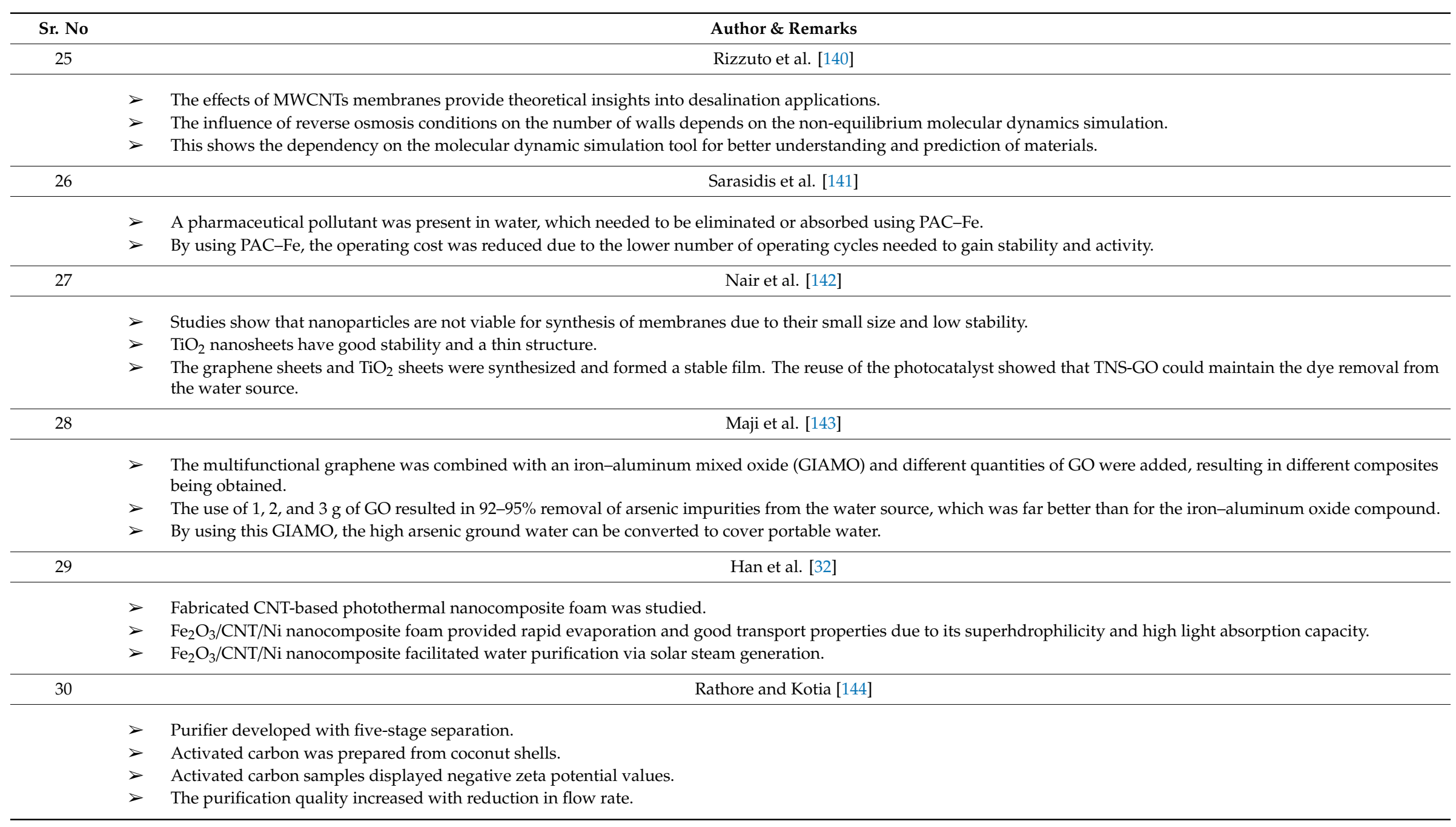




\section{Conclusions}

In the present paper, a comprehensive review was performed of recent developments related to water purification technology using carbon materials. The most relevant patents and papers published in the last decade were carefully selected. In the initial stage, fabrication and structural properties were discussed. Adsorption is a well-established method for water purification. Activated carbon, CNTs, GO, and rGO have been widely tested for adsorptive removal of impurities due to their superior physicochemical properties. The FESEM image of activate carbon displayed macropores on its surface, with an internal surface area of up to $1500 \mathrm{~m}^{2} / \mathrm{g}$. Improvements in effectiveness have been achieved by combining carbon nanomaterials with other nanoparticles (activated carbon- $\mathrm{Fe}_{3} \mathrm{O}_{4}$ nanoparticle composites) and through structural modifications (vertically aligned CNTs). These are new approaches that can improve the effectiveness and efficiency.

The recent patents over the last decade related to water purification technologies using carbon materials were discussed. Activated carbon is the most widely used carbon material in either original or combined form. The recent research articles on water purification using carbon materials were also covered. The hydrophilic surfaces of CNTs enable backwashing and rinsing. The use of carbon materials in combined form, such as MWCNT-Z $\mathrm{rO}_{2}, \mathrm{rGO}-\mathrm{Ti}$, and GO-Ag, are recent attempts at improving the effectiveness of water purification. The usage of carbon nanomaterials as nanoelectrodes adds one more reason for their application as water purification materials.

In conclusion, carbon-based materials can be used for small- and large-scale water purification technologies. They are cost-effective and eco-friendly options, which have experienced a steady increase in attention from the research community.

Author Contributions: Conceptualization, A.K. and M.G.K.; methodology, A.K.; investigation, A.Y. and T.R.R.; data curation, H.R.; writing-original draft preparation, A.K. and M.G.K.; writing-review and editing, I.E.S.; visualization, A.K.; supervision, I.E.S. All authors have read and agreed to the published version of the manuscript.

Funding: This research received no external funding.

Conflicts of Interest: The authors declare no conflict of interest.

\section{References}

1. Virender, K.S.; McDonald, T.J.; Kim, H.; Garg, V.K. Magnetic graphene-carbon nanotube iron nanocomposites as adsorbents and antibacterial agents for water purification. Adv. Colloid Interface Sci. 2015, 225, 229-240.

2. Allen, M.J.; Tung, V.C.; Kaner, R.B. Honeycomb Carbon: A Review of Graphene. Chem. Rev. 2009, 110, 132-145. [CrossRef]

3. Kar, S.; Bindal, R.C.; Tewari, P.K. Carbon nanotube membranes for desalination and water purification: Challenges and opportunities. Nano Today 2012, 7, 385-389. [CrossRef]

4. Nasrabadi, A.T.; Foroutan, M. Ion-separation and water-purification using single-walled carbon nanotube electrodes. Desalination 2011, 277, 236-243. [CrossRef]

5. Sharma, V.K.; Filip, J.; Zboril, R.; Varma, R.S. Natural inorganic nanoparticles-Formation, fate, and toxicity in the environment. Chem. Soc. Rev. 2015, 44, 8410-8423. [CrossRef]

6. Chang, C.-F.; Truong, Q.D.; Chen, J.-R. Graphene sheets synthesized by ionic-liquid-assisted electrolysis for application in water purification. Appl. Surf. Sci. 2013, 264, 329-334. [CrossRef]

7. Sreeprasad, T.; Maliyekkal, S.M.; Lisha, K.; Pradeep, T. Reduced graphene oxide-metal/metal oxide composites: Facile synthesis and application in water purification. J. Hazard. Mater. 2011, 186, 921-931. [CrossRef]

8. Goh, P.S.; Ismail, A.F.; Ng, B.C. Carbon nanotubes for desalination: Performance evaluation and current hurdles. Desalination 2013, 308, 2-14. [CrossRef]

9. Hu, J.-S.; Zhong, L.-S.; Song, W.-G.; Wan, L.-J. Synthesis of hierarchically structured metal oxides and their application in heavy metal ion removal. Adv. Mater. 2008, 20, 29772008. [CrossRef]

10. Liu, Y.; Li, Y.; Yan, X.-P. Preparation, characterization, and application of L.-cysteine functionalized multiwalled carbon nanotubes as a selective sorbent for separation and preconcentration of heavy metals. Adv. Funct. Mater. 2008, 18, 1536-1543. [CrossRef] 
11. Chengfeng, R.; Rongrong, R. Get Rid of Chlorine Residue Active Carbon Water Purification Filter Core. U.S. Patent CN08791367U, 26 April 2019.

12. Song, B.; Jian, L.; Honghu, P.; Shunpeng, Z.; Zhonghua, Z.; Jianqi, Z.; Guocheng, Z. Corncob Active Carbon Water Purification Filter Core. U.S. Patent CN204918207U, 2 October 2015.

13. Du, H. Active Carbon Water Purification Device with Automatic Flushing and Pollutant Discharge Functions. U.S. Patent CN201678532U, 26 March 2010.

14. Jie, L.; Min, L.; Jing, X. Active Carbon Water Purification Unit. U.S. Patent CN207478059U, 12 June 2018.

15. Triestam, A. Hot Water Heater Has Water Container with Electrical Heating Body, Replaceable Active Carbon Water Filter(s) and/or UV Radiation Source(s); Water Flows Through Filter and/or Past UV Source. U.S. Patent DE19946064A1, 16 December 1999.

16. Archer, V.L. Activated Carbon Water Filter. U.S. Patent CN209397001U, 17 September 2019.

17. Gehrke, I.; Geiser, A.; Somborn-Schulz, A. Innovations in nanotechnology for water treatment. Nanotechnol. Sci. Appl. 2015, 8, 1-17. [CrossRef]

18. Pezoti, O.; Cazetta, A.L.; Bedin, K.C.; Souza, L.S.; Martins, A.C.; Silva, T.L.; Júnior, O.O.S.; Visentainer, J.V.; Almeida, V.C. NaOH-activated carbon of high surface area produced from guava seeds as a high-efficiency adsorbent for amoxicillin removal: Kinetic, isotherm and thermodynamic studies. Chem. Eng. J. 2015, 288, 778-788. [CrossRef]

19. Dąbrowski, A.; Podkościelny, P.; Hubicki, Z.; Barczak, M. Adsorption of phenolic compounds by activated carbon-A critical review. Chemosphere 2005, 58, 1049-1070. [CrossRef]

20. Cheng, W.; Dastgheib, S.A.; Karanfil, T. Adsorption of dissolved natural organic matter by modified activated carbons. Water Res. 2005, 39, 2281-2290. [CrossRef]

21. Brady-Estévez, A.S.; Kang, S.; Elimelech, M. A Single-Walled-Carbon-Nanotube Filter for Removal of Viral and Bacterial Pathogens. Small 2008, 4, 481-484. [CrossRef]

22. Baek, Y.; Kim, C.; Seo, D.K.; Kim, T.; Lee, J.S.; Kim, Y.H.; Ahn, K.H.; Bae, S.S.; Lee, S.C.; Lim, J.; et al. High performance and antifouling vertically aligned carbon nanotube membrane for water purification. J. Membr. Sci. 2014, 460, 171-177. [CrossRef]

23. Dong, X.; Yang, L. Dual functional nisin-multi-walled carbon nanotubes coated filters for bacterial capture and inactivation. J. Biol. Eng. 2015, 9, 1-10. [CrossRef]

24. Ain, Q.-U.-; Farooq, M.U.; Jalees, M.I. Application of magnetic graphene oxide for water purification: Heavy metals removal and disinfection. J. Water Process. Eng. 2019, 33, 101044. [CrossRef]

25. Lujanienè, G.; Šemčuk, S.; Lečinskytè, A.; Kulakauskaitè, I.; Mažeika, K.; Valiulis, D.; Pakštas, V.; Skapas, M.; Tumènas, S. Magnetic graphene oxide based nano-composites for removal of radionuclides and metals from contaminated solutions. J. Environ. Radioact. 2016, 166, 166-174. [CrossRef]

26. Wang, J.; Chen, B. Adsorption and coadsorption of organic pollutants and a heavy metal by graphene oxide and reduced graphene materials. Chem. Eng. J. 2015, 281, 379-388. [CrossRef]

27. Zhang, Y.; Yan, L.; Xu, W.; Guo, X.; Cui, L.; Gao, L.; Wei, Q.; Du, B. Adsorption of Pb(II) and Hg(II) from aqueous solution using magnetic CoFe2O4-reduced graphene oxide. J. Mol. Liq. 2013, 191, 177-182. [CrossRef]

28. Do, M.H.; Phan, N.H.; Nguyen, T.K.P.; Pham, T.T.S.; Nguyen, V.K.; Vu, T.T.T. Activated carbon/Fe $3 \mathrm{O}_{4}$ nanoparticle composite: Fabrication, methyl orange removal and regeneration by hydrogen peroxide. Chemosphere 2011, 85, 1269-1276. [CrossRef]

29. Gusain, R.; Kumar, N.; Ray, S.S. Recent advances in carbon nanomaterial-based adsorbents for water purification. Co-ord. Chem. Rev. 2020, 405, 213111. [CrossRef]

30. Dimiev, A.M.; Alemany, L.B.; Tour, J.M. Graphene oxide. Origin of acidity, its instability in water, and a new dynamic structural model. ACS Nano 2013, 7, 576-588. [CrossRef]

31. Sun, L. Structure and synthesis of graphene oxide. Chin. J. Chem. Eng. 2019, 27, 2251-2260. [CrossRef]

32. Han, S.; Yang, J.; Li, X.; Li, W.; Zhang, X.; Koratkar, N.; Yu, Z. Flame synthesis of superhydrophilic carbon nanotubes/ni foam decorated with fe2onanoparticles for water purification via solar steam generation. ACS Appl. Mater. Interfaces 2020, 12, 13229-13238. [CrossRef]

33. Li, M.; Liang, S.; Wu, Y.; Yang, M.; Huang, X. Cross-stacked super-aligned carbon nanotube/activated carbon composite electrodes for efficient water purification via capacitive deionization enhanced ultrafiltration. Front. Environ. Sci. Eng. 2020, 14, 107. [CrossRef] 
34. Libing, Q.; Yabei, T.; Yanqing, X.; Ning, L. Modified Basalt Fibre Applied to Water Quality Purification. CN107262042A, 20 October 2017.

35. Duan, C.; Ma, T.; Wang, J.; Zhou, Y. Removal of heavy metals from aqueous solution using carbon-based adsorbents: A review. J. Water Process. Eng. 2020, 37, 101339. [CrossRef]

36. Yadav, S.; Saleem, H.; Ibrar, I.; Naji, O.; Hawari, A.A.; AlAnezi, A.A.; Zaidi, S.J.; Altaee, A.; Zhou, J. Recent developments in forward osmosis membranes using carbon-based nanomaterials. Desalination 2020, 482, 114375. [CrossRef]

37. Sweetman, M.J.; May, S.; Mebberson, N.; Pendleton, P.; Vasilev, K.; Plush, A.S.E.; Hayball, J.D. Activated carbon, carbon nanotubes and graphene: Materials and composites for advanced water purification. J. Carbon Res. 2017, 3, 18. [CrossRef]

38. Li, Y.; Zhang, M. Mechanical properties of activated carbon fibers. In Activated Carbon Fiber and Textiles; Woodhead Publishing: Sawston, UK, 2017; pp. 167-180.

39. Dresselhaus, M.S.; Lin, Y.; Rabin, O.; Jorio, A.; Filho, A.S.; Pimenta, M.; Saito, R.; Samsonidze, G.; Dresselhaus, G. Nanowires and nanotubes. Mater. Sci. Eng. C 2003, 23, 129-140. [CrossRef]

40. Ahn, C.H.; Baek, Y.; Lee, C.; Kim, S.O.; Kim, S.; Lee, S.; Kim, S.-H.; Bae, S.S.; Park, J.; Yoon, J. Carbon nanotube-based membranes: Fabrication and application to desalination. J. Ind. Eng. Chem. 2012, 18, 1551-1559. [CrossRef]

41. Hinds, B.J.; Chopra, N.; Rantell, T.; Andrews, R.; Gavalas, V.; Bachas, L.G. Aligned Multiwalled Carbon Nanotube Membranes. Science 2004, 303, 62-65. [CrossRef]

42. Choi, Y.C.; Shin, Y.M.; Lee, Y.H.; Lee, B.S.; Park, G.-S.; Choi, W.B.; Lee, N.S.; Kim, J.M. Controlling the diameter, growth rate, and density of vertically aligned carbon nanotubes synthesized by microwave plasma-enhanced chemical vapor deposition. Appl. Phys. Lett. 2000, 76, 2367-2369. [CrossRef]

43. Holt, J.K.; Noy, A.; Huser, T.; Eaglesham, A.D.; Bakajin, O. Fabrication of a carbon nanotube-embedded silicon nitride membrane for studies of nanometer-scale mass transport. Nano Lett. 2004, 4, 2245-2250. [CrossRef]

44. Hofmann, U.; Holst, R. Über die säurenatur und die methylierung von graphitoxyd. Ber. Dtsch. Chem. Ges. 2006, 72, 754. [CrossRef]

45. Ruess, G. Über das graphitoxyhydroxyd (graphitoxyd). Chem. Mon. 1947, 76, 381-417. [CrossRef]

46. Hummers, W.S., Jr.; Offeman, R.E. Preparation of graphitic oxide. J. Am. Chem. Soc. 1958, 80, 1339. [CrossRef]

47. Wu, Z.; Chen, Z.; Du, X.; Logan, M.J.; Sippel, J.; Nikolou, M.; Kamaras, K.; Reynolds, J.R.; Tanner, D.; Hebard, A.F.; et al. Transparent, conductive carbon nanotube films. Science 2004, 305, 1273-62004. [CrossRef]

48. Liu, H.; Wang, H.; Zhang, X. Facile fabrication of freestanding ultrathin reduced graphene oxide membranes for water purification. Adv. Mater. 2015, 27, 249-254. [CrossRef]

49. Qianfeng, L. Graphene Water Purifier. U.S. Patent CN109502896A, 22 March 2019.

50. Longjingling, H.; Information Tech Co. Ltd. A Kind of Multiple-Effect Water Treatment Agent and Preparation Method thereof and Method for Treating Water. U.S. Patent CN107265530A, 20 October 2017.

51. Liangti, Q.; Cheng, H.; Zhang, P.P. Graphene Solar Energy Water Cleaning Foam as Well as Preparation Method and Application. U.S. Patent CN108002366A, 8 May 2018.

52. Hostetter, W.E. Carbon Water Filter. U.S. Patent US3612279A, 12 October 1971.

53. Tarifi, M.H. PCO/UVC/Carbon Water Filter. U.S. Patent US2014166591A1, 19 June 2014.

54. Frank, A.; Brigano, J.; Schroeder, H.; Popovic, V. Activated Carbon Water Filter with Reduced Leachable Arsenic and Method for Making the Same. U.S. Patent WO2010144175A1, 16 December 2010.

55. Chen, T. Active Carbon Water Treatment Agent. U.S. Patent CN107555518A, 9 January 2018.

56. Yan, Z.; Li, M. Aqua Pure Extract System and Method Are Used in Health Preserving Wine Production. U.S. Patent CN106830474A, 13 June 2017.

57. Zhao, W.; Jiang, Y.; Lin, X.; Wang, L.; Guo, S.; Shen, J.; Peng, P.; Wang, D. A Kind of Rural Area Sub-Prime of Energy-Saving and Emission-Reduction is for Water Purification Integral System. U.S. Patent CN109081477A, 25 December 2018.

58. Iang, Y. Energy-Saving and Water-Saving Type Water Purifier. U.S. Patent CN103043836A, 17 April 2013.

59. Wang, Y.; Wang, P.; Lin, Y.; Zhang, X.; Zhang, K.; Chen, T. A Kind of Active Carbon Filter Core that Household Water Filter is Conveniently Replaceable. U.S. Patent CN209361991U, 10 September 2019. 
60. Gao, X. Possesses the Activated Carbon Filter of Stirring Mixed Function. U.S. Patent CN107298506A, 27 October 2017.

61. Pan, L. A Kind of Preparation Method of Sintering Activity Charcoal Water Purification Catridge. U.S. Patent CN109250781A, 22 January 2018.

62. Tu, Y. Silver Loaded Activated Carbon Water Purification Filter Element. U.S. Patent CN203002379U, 19 June 2013.

63. Zhu, X.; Liu, Y. Ozone-Biological Activated Carbon Water Purification Method and Device. U.S. Patent CN102126809B, 30 May 2012.

64. Huang, Y. Negative-Ion Sintered Activated Carbon Water Purification Filter Element and Preparation Method Thereof. U.S. Patent CN105481045A, 13 April 2016.

65. Chen, C. Active Carbon Water Purification Device is Used in a Kind of Production of Drinking Mineral Water. U.S. Patent CN209537118U, 25 October 2019.

66. Wang, L. Activated Carbon Water Purification Device and Preparation Method. U.S. Patent CN103055808A, 24 April 2013.

67. Lee, S.-H. Large-Capacity Water Treatment Apparatus Having Improved Activated Carbon Water-Purification and Regeneration Function. U.S. Patent WO2016190525A1, 1 December 2016.

68. Gappa, G.; Juentgen, H.; Klein, J.; Reichenberger, J. Activated-Carbon Water Purification Controlled by Analysis of Carbon Content in Water. U.S. Patent CA1048940A, 20 February 1979.

69. Shifeng, B.H.; Nuannuan, J.; Liang, M.; Mingjuan, S.; Yuanyuan, W. Method for Preparing Graphene Oxide Water Purifying Filter Core. U.S. Patent CN103785223A, 14 May 2014.

70. Feng, J.; Liang, S. Self-Cleaning Active Carbon Filter Cartridge Device. U.S. Patent CN203803176U, 3 September 2014.

71. Zhao, J. Activated-Carbon Filter Cored Structure Water Purification Machine. U.S. Patent CN204058096U, 31 December 2014.

72. Zhang, Y. A Kind of Household Active Charcoal Filter Core. U.S. Patent CN204342473U, 20 May 2015.

73. Hou, Y. Front Activated Carbon Filter Cartridge-Free Drinking Fountain. U.S. Patent CN101935114A, 5 January 2011.

74. Li, T.; Qiu, J. Making Method of Negative Ion-Sintered Active Carbon Water Purification Filter Core. U.S. Patent CN103588257A, 19 February 2013.

75. Hyu, I. Carbon Nanoparticle for Photocatalyst. KR101495124B1, 24 February 2015.

76. Magnusson, J.H. Iodine Resin/Carbon Water Purification System. U.S. Patent CA2052200A1, 28 March 1992.

77. Claus, F.; Hailong, D.; Ana, K.; Dorothee, G. Carbon Dots (c Dots) Method for Their Preparation and Their Use. EP2913300A1, 2 September 2015.

78. Zhang, H.; Qiu, M.; Zhang, J. Water Purification Composite Material and Preparation Method and Application Thereof. U.S. Patent CN107352627A, 17 November 2017.

79. Nobuyuki, S.; Hideo, U. Holder for Activated-Carbon Filter Cartridge. U.S. Patent JPS6295499A, 1 May 1987.

80. Magnusson, J.; Magnusson, K.J. System Made of Iodine-Containing Resin and Carbon for Water Purification. U.S. Patent DE69103366T, 16 December 1990.

81. ELS Business Group International LLC. Carbon Water Filter. U.S. Patent TH53392B, 7 October 2002.

82. CHE, C. Preparation Method of Graphene Water Purifier Filter Core. U.S. Patent CN108190994A, 22 June 2018.

83. Xiuan, A. Ecological Agriculture Co LTD. Compound for Purifying Water. U.S. Patent CN107720976A, 22 June 2018.

84. Yang, J.-L. An Improved Reverse Osmosis/Activated Carbon Water Filter with Automatic Forced Self-Cleaning Function. U.S. Patent TW311477U, 21 June 1997.

85. Li, N.; Qian, L.; Tan, Y.; Xu, Y. A Kind of Treated Basalt Fiber Applied to Purification of Water Quality. U.S. Patent CN107262042A, 20 October 2017.

86. Wang, Y. Dynamic-Static Combined Multistage Filter Bed Cyclone Magnetization Water Purifier. U.S. Patent CN104058542A, 24 September 2014.

87. Wang, G. Rotational Flow Magnetizing Water Purifier with Dynamic and Static Combination Multistage Filter Bed. U.S. Patent CN203269713U, 6 November 2013.

88. Xue, J. Water Saving Water Purifier. U.S. Patent CN201962142U, 7 September 2011.

89. Fan, J. A Kind of Novel High Efficiency Water Purifier Equipment for Modern Plant. U.S. Patent CN204619525U, 9 September 2015. 
90. Gao, X. The Activated Carbon Filter of Multi-Filtering. U.S. Patent CN107311378A, 3 November 2017.

91. Wang, M.; Wu, X. A Kind of Low Waste Water Purifier of Energy-Conserving and Environment-Protective. U.S. Patent CN207016571U, 16 February 2018.

92. Fu, S.; He, L.; Peng, H.; Sun, P.; Xie, M. A Kind of Composition Type Clear Water Machine. U.S. Patent CN203938535U, 12 November 2014.

93. Yabing, S.; Dong, H.; Shunbin, L.; Lin, B.; Yan, Z.; Sujie, L.; Zehua, Z.; Shaopeng, R. Multi-Functional Water Purifier Integrated with Activated Carbon and Low-Temperature Plasma. U.S. Patent CN103145284B, 5 November 2014.

94. Gong, C. A Kind of Novel Anti-Freezing Water Purifier. U.S. Patent CN207108646U, 16 March 2018.

95. Deng, S. A Kind of Tap Water Purifier with Active Carbon Backwash Function. U.S. Patent CN109850977A, 7 June 2019.

96. Huang, H.; Huang, L.; Huang, R. A Kind of RO Water Purifier. U.S. Patent CN208747829U, 16 April 2019.

97. Zheng, L. A Kind of Energy-Saving Water Purifier with Multistage Filtering Function. U.S. Patent CN107473475A, 15 December 2017.

98. Lee, C.G. A Domestic Water Purifier Equipped Outdoor. U.S. Patent KR20030070267A, 30 August 2003.

99. Wu, X. Ultrafiltration Water Purification Machine with Water Intake Pressure Adjustment and Display Functions. U.S. Patent CN203728654U, 23 July 2014.

100. Wang, W. A Kind of Novel Intelligent Water Purifier for Family's Water Purification. U.S. Patent CN204644006U, 16 September 2015.

101. Tong, X. Rear-Mounted Water Purifier of Four-Core. U.S. Patent CN205346992U, 29 June 2016.

102. Pan, W. Water-Saving Water Purifier. U.S. Patent CN105800813A, 27 July 2016.

103. Wang, J. Pressure Charged Heating Water Purifier. U.S. Patent CN204111513U, 21 January 2015.

104. Cheng, Z. A Outdoor Water Purifier for Water Treatment. U.S. Patent CN205473053U, 17 August 2016.

105. Zhu, L. High-Precision Ultrafiltration Water Purifier and Water Purification Method Thereof. U.S. Patent CN103979695A, 13 August 2014.

106. Liu, C. Wastewater-Free Water Purifier. U.S. Patent CN107867764A, 3 April 2018.

107. Ma, Z. The Outdoor Water Purifier of Ceramic Element. U.S. Patent CN204454785U, 8 July 2015.

108. He, D. Ultra-Low-Pressure Reverse Osmosis Water Purifier. U.S. Patent CN206368080U, 1 August 2017.

109. Hui, D.; Yong, W.; Yongshu, Z. A Kind of Wall-Hanging Water Purifier that RO Membrane Cartridge Is Set. U.S. Patent CN204224339U, 25 March 2015.

110. Bin, Y. A Kind of Filter Element of Water Purifier Convenient for Recycling Waste Water. U.S. Patent CN207891156U, 21 September 2018.

111. Chen, J.; Dong, C.; Lu, Q.; Si, D.; Zhang, D.; Zhang, Y. Water Purifier without Wastewater Discharge. U.S. Patent CN105384274A, 9 March 2016.

112. Haitao, Y. Electrostatic Activated Carbon Filter Element of Water Purifier. U.S. Patent CN108217804A, 29 June 2018.

113. Qiang, Y. Hydroelectric Separation Water Purifier. U.S. Patent CN208843834U, 10 May 2019.

114. Xiaofei, L. Water Purifier. CN202415284U, 5 September 2012.

115. Chen, Y. RO (Reverse Osmosis) Water Purifier of Pressure-Free Barrel. U.S. Patent CN202808504U, 20 March 2013.

116. Wang, H.; Wang, P. A Kind of Novel Water Purifier. U.S. Patent CN204550255U, 12 August 2015.

117. Feng, W. Constant-Pressure Water Purifier Using Water Purifying Agent. U.S. Patent CN104671528A, 3 June 2015.

118. Zeng, R. Vertical Water Purifier. U.S. Patent CN207192981U, 6 April 2018.

119. Ntim, S.A.; Mitra, S. Adsorption of arsenic on multiwall carbon nanotube-zirconia nanohybrid for potential drinking water purification. J. Colloid Interface Sci. 2012, 375, 154-159. [CrossRef]

120. Beobide, A.S.; Anastasopoulos, J.; Voyiatzis, G.A.; Lainioti, G.C.; Kallitsis, J.; Kouravelou, K. Embedment of functionalized carbon nanotubes into water purification membrance. Procedia Eng. 2012, 44, 1918-1919. [CrossRef]

121. Bakajin, O.; Noy, A.; Fornasiero, F.; Grigoropoulos, C.P.; Holt, J.K.; Bin Kim, S.; Park, H.G. Nanofluidic carbon nanotube membranes: Applications for water purification and desalination. In Nanotechnology Applications for Clean Water, 2nd ed.; Elsevier Inc.: Oxford, UK; Waltham, MA, USA, 2009. [CrossRef] 
122. Das, R.; Ali, E.; Bee, S.; Hamid, A.; Ramakrishna, S.; Zaman, Z. Carbon nanotube membranes for water puri fi cation: A bright future in water desalination. DES 2014, 336, 97-109. [CrossRef]

123. Masinga, S.P.; Nxumalo, E.N.; Mamba, B.B.; Mhlanga, S.D. Microwave-induced synthesis of b-cyclodextrin/ $\mathrm{N}$-doped carbon nanotube polyurethane nanocomposites for water purification. J. Phys. Chem. Ear 2013. [CrossRef]

124. Zhang, Q.; Lu, Z.; Jin, S.; Zheng, Y.; Ye, T.; Yang, D.; Li, Y.; Zhu, L.; Zhu, L. TiO 2 nanotube-carbon macroscopic monoliths with multimodal porosity as efficient recyclable photocatalytic adsorbents for water purification. Math. Chem. Phys. 2016,1-8. [CrossRef]

125. Nguyen-phan, T.; Hung, V.; Jung, E.; Oh, E.; Hyun, S.; Suk, J.; Lee, B.; Woo, E. Applied surface science reduced graphene oxide-titanate hybrids: Morphologic evolution by alkali-solvothermal treatment and applications in water purification. Appl. Surf. Sci. 2012, 258, 4551-4557. [CrossRef]

126. Peng, F.; Luo, T.; Qiu, L.; Yuan, Y. An easy method to synthesize graphene oxide-FeOOH composites and their potential application in water purification. Mater. Res. Bull. 2013, 48, 2180-2185. [CrossRef]

127. Sun, X.; Qin, J.; Xia, P.; Guo, B.; Yang, C.; Sun, X.; Qin, J.; Xia, P.; Guo, B.; Yang, C.; et al. Graphene oxide-silver nanoparticle membrane for biofouling control and water purification. Chem. Eng. J. 2015. [CrossRef]

128. Manafi, M.; Manafi, P.; Agarwal, S.; Bharti, A.K.; Asif, M.; Gupta, V.K. Synthesis of Nanocomposites from Polyacrylamide and Graphene Oxide: Application as flocculants for water purification. J. Colloid Interface Sci. 2016. [CrossRef]

129. Lompe, K.M.; Menard, D.; Barbeau, B. Performance of biological magnetic powdered activated carbon for drinking water purification. Water Res. 2016. [CrossRef]

130. Kim, S.; Song, Y.; Ibsen, S.; Ko, S.; Heller, M.J. Controlled degrees of oxidation of nanoporous graphene filters for water purification using an aqueous arc discharge. Carbon 2016, 109, 624-631. [CrossRef]

131. Yin, J.; Zhu, G.; Deng, B. Graphene oxide (GO) enhanced polyamide (PA) thin-film nanocomposite (TFN) membrane for water purification. Desalination 2015, 379, 93-101. [CrossRef]

132. Gondal, M.A.; Ilyas, A.M.; Baig, U. Facile synthesis of silicon carbide-titanium dioxide semiconducting nanocomposite using pulsed laser ablation technique and its performance in photovoltaic dye sensitized solar cell and photocatalytic water purification. Appl. Surf. Sci. 2016. [CrossRef]

133. Pawar, R.C.; Choi, D.; Lee, C.S. Reduced graphene oxide composites with MWCNTs and single crystalline hematite nanorhombohedra for applications in water purification. Int. J. Hydrogen Energy 2014, 1-12. [CrossRef]

134. Tuan, T.N.; Chung, S.; Lee, J.K.; Lee, J. Improvement of water softening efficiency in capacitive deionization by ultra purification process of reduced graphene oxide. Curr. Appl. Phys. 2015. [CrossRef]

135. Pudza, M.Y.; Abidin, Z.Z.; Rashid, S.A.; Yasin, F.M.; Noor, A.S.M.; Issa, M.I. Eco-Friendly Sustainable Fluorescent Carbon Dots for the Adsorption of Heavy Metal Ions in Aqueous Environment. Nanomaterials 2020, 10, 315. [CrossRef]

136. Xu, C.; Cui, A.; Xu, Y.; Fu, X. Graphene oxide- $-\mathrm{TiO}_{2}$ composite filtration membranes and their potential application for water purification. Carbon 2013, 62, 465-471. [CrossRef]

137. Hegab, H.M.; Zou, L. Graphene oxide-assisted membranes: Fabrication and potential applications. J. Membr. Sci. 2015. [CrossRef]

138. Gamage, S.M.; Sathasivan, A. Chemosphere A review: Potential and challenges of biologically activated carbon to remove natural organic matter in drinking water puri fi cation process. Chemosphere 2017, 167, 120-138. [CrossRef]

139. Raghu, M.S.; Kumar, K.Y.; Prashanth, M.K.; Prasanna, B.P.; Vinuth, R.; Kumar, C.B.P. Adsorption and antimicrobial studies of chemically bonded magnetic graphene oxide-Fe3O4 nanocomposite for water purification. J. Water Process Eng. 2017, 17, 22-31. [CrossRef]

140. Rizzuto, C.; Pugliese, G.; Bahattab, M.A.; Aljlil, S.A.; Drioli, E.; Tocci, E. Multiwalled carbon nanotube membranes for water purification. separation and purification technology. Sep. Purif. Technol. 2017. [CrossRef]

141. Sarasidis, C.V.; Plakas, V.K.; Karabela, J.A. Novel water-purification hybrid processes involving in-situ regenerated activated carbon, membrane separation and advanced oxidation. Chem. Eng. J. 2017. [CrossRef]

142. Nair, A.; Ponnan, E.; Jagadeesh, B.B. $\mathrm{TiO}_{2}$ nanosheet-graphene oxide based photocatalytic hierarchical membrane for water purification. Surf. Coat. Technol. 2017, 320. [CrossRef] 
143. Maji, S.; Ghosh, A.; Gupta, K.; Ghosh, A.; Ghorai, U.; Santra, A.; Sasikumar, P.; Ghosh, U.C. Efficiency evaluation of arsenic(III) adsorption of novel graphene oxide@iron-aluminium oxide composite for the contaminated water purification. Sep. Purif. Technol. 2018. [CrossRef]

144. Rathore, P.; Kotia, A. Gravity water purifier using activated carbon form coconut shell for rural application. Plant Arch. 2020, 20, 2626-2640.

Publisher's Note: MDPI stays neutral with regard to jurisdictional claims in published maps and institutional affiliations.

(C) 2020 by the authors. Licensee MDPI, Basel, Switzerland. This article is an open access article distributed under the terms and conditions of the Creative Commons Attribution (CC BY) license (http://creativecommons.org/licenses/by/4.0/). 